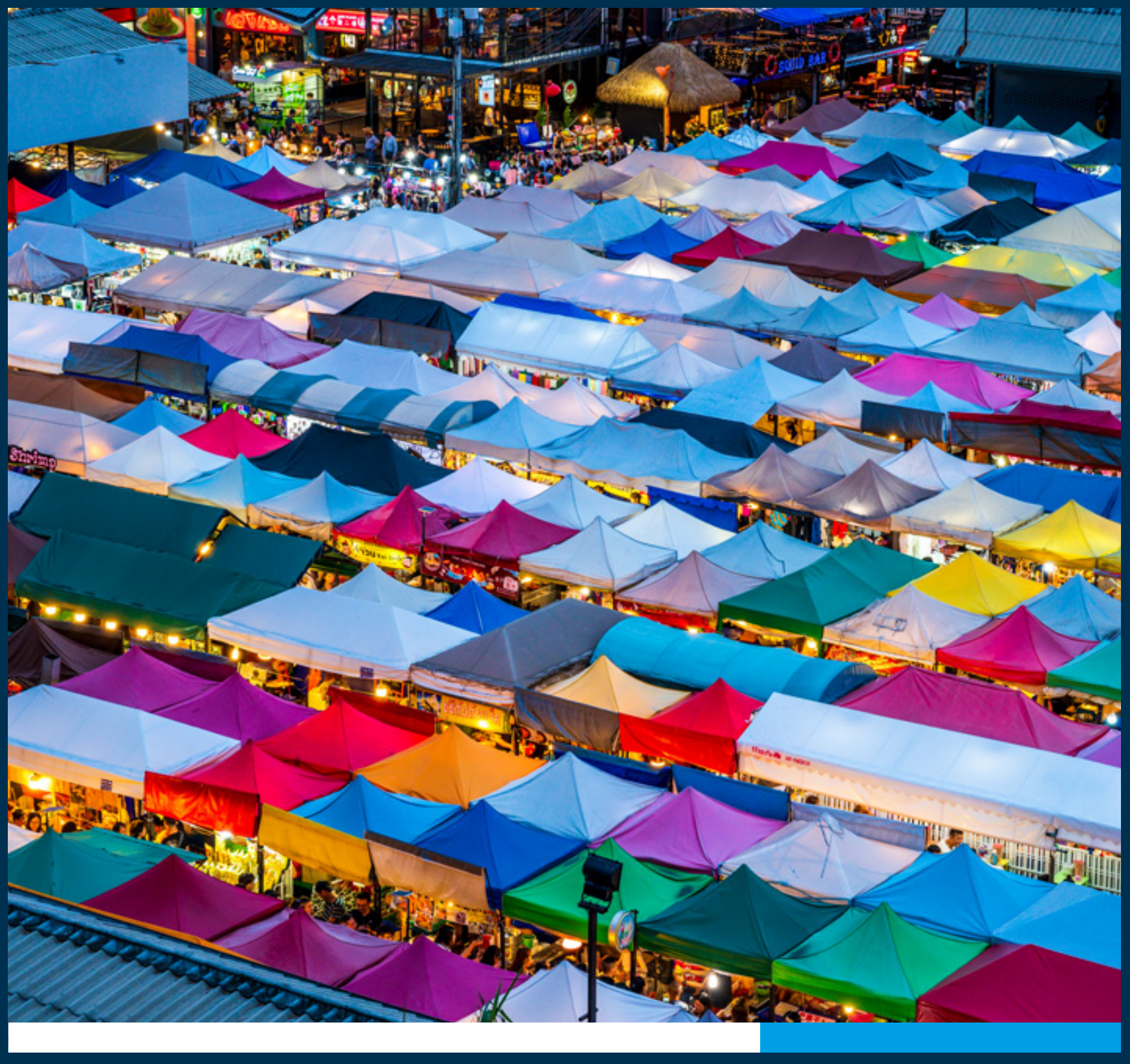

\title{
REBUILDING TOURISM COMPETITIVENESS
}

Tourism response, recovery and resilience to the COVID-19 crisis

Markets \& Technology Global Tourism Team | July 2020 


\section{Acknowledgements}

This note was authored by the World Bank Group's Markets \& Technology Global Tourism Team including John Perrottet, Hannah Messerli, Louise Twining-Ward, Shaun Mann, Hermione Nevill, Jessie McComb and Andrew Beath under the guidance of Markets and Technology Practice Manager Martha Licetti, and Global Director for Trade, Investment and Competitiveness Caroline Freund. The team is grateful to technical reviewers who provided insight and guidance at various stages of the production of the note including Mariem Malouche, Kiran Afzal, Tanja Goodwin, Andres Garcia, and Zenaida Hermandez Uriz. Valuable contributions were provided by Emiliano Duch, Wouter Schalken, Jose Miguel Villascusa Cerezo, Jan Kazimierz Orlowski, Ana Cristina Alonso Soria, Gemma Torras Vives, Dennis Sanchez Navarro and Jessica Wilson.

The note responds to the COVID-19 crisis that hit the tourism sector in the first quarter of 2020. The crisis is ongoing, so any recommendations made in this report should be considered through the lens of developments that have taken place in the intervening period.

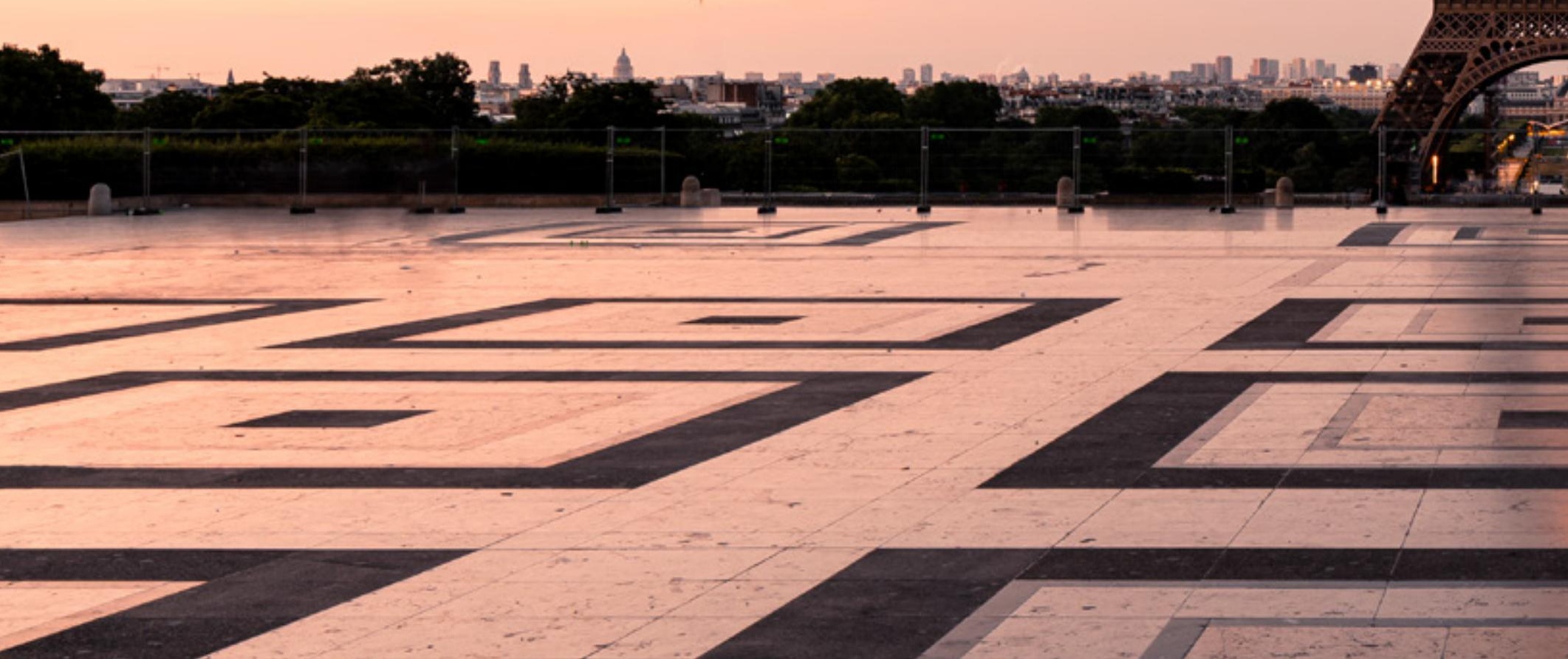


Table of Contents

EXECUTIVE SUMMARY

1. GLOBAL CONTEXT AND CURRENT IMPACT 6

2. SECTOR IMPACTS AND

COUNTRY VULNERABILITIES

Sector Impacts

Aviation

Accommodation and Lodging

Tour Operators

Cruise Operators

Digital Platforms

Global Distribution Systems

Other Sectors and Impacts on Global Value Chains

\section{COUNTRY IMPACTS}

AND VULNERABILITIES

Tourism Dependence

Tourism Resilience Risk

Tourism Demand Impact on Recovery
4

10

12

12

13

14

14

14

16

17

18

20

\section{POLICY RESPONSES}

24

The World Bank Group and Past Crises

Thinking Forward in the Context

27

of Uncertainty

Advice for World Bank Clients

Phase 1: Immediate Response (during the crisis and early recovery)

Phase 2 Recovery: Short-term

Phase 3 Recovery: Medium-term

31

\section{CLOSING CONSIDERATIONS}

Appendix 1: Global Aviation Data

Appendix 2: Regional and Country

Vulnerability Data of Tourism: Economic

Dependence and Tourism Resilience

Risk Score

Appendix 3: Menu of Response Options

Endnotes

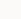




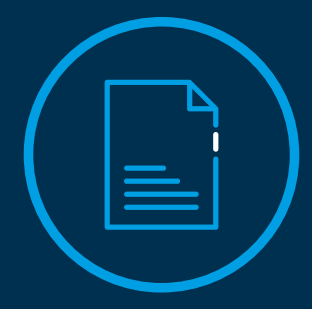

\section{Executive Summary}

The travel and tourism industry was one of the first sectors to be affected by COVID-19. Since March, the entire value chain that defines the industry - spanning airlines, bus and train companies, cruise lines, hotels, restaurants, attractions, travel agencies, tour operators, online travel entities, and others - has entered a state of suspended animation. While bankruptcies of major airlines and large tour operators have been widely reported, the effects of the crisis are perhaps being most acutely felt by the Small and Medium-sized Enterprises (SMEs) that make up around 80 percent of licensed tourism and tourism-related businesses, and are at the greatest risk of failure. Their potential collapse threatens to adversely affect millions of people across the world, including many vulnerable communities, who depend on tourism for their livelihoods. According to the World Travel \& Tourism Council, as many as 100 million jobs supported by travel and tourism are currently at risk.

The COVID-19 pandemic will undoubtedly leave a deep imprint on the structure of the travel and tourism industry. Collapsing consumer demand, low cash reserves, and a lack of access to flexible lines of credit has forced many smaller travel and tourism operators to close. At the same time, while larger firms such as national airlines, tour operators, cruise lines and nationally branded hotel operators are better positioned to withstand the crisis, they are also facing significant challenges as demand is not recovering anytime soon. While some agile players have repurposed their offering, the pandemic is likely to fuel consolidation - and potentially vertical integration-across the sector. While in the short-term there is a risk of widespread discounting to attract visitors to return, in the medium to long-term consolidation may spur price increases and reductions in the range and quality of services. Consequently, the travel and tourism sector that will emerge from the pandemic is likely to be smaller, in terms of both employment and revenue, than it was before. The process of consolidation and vertical integration is also likely to curtail opportunities provided by the sector for operators from developing countries. 
The broader economic impacts of the slump in travel and tourism on individual countries and destinations will vary depending on their economic dependence on tourism and their resilience, as well as the dynamics of demand in their key source markets. The global economic and pandemic uncertainty is therefore a key limiting factor for both source markets and destinations. Countries that are highly dependent on tourism include many small island countries, as well as lower and lower-middle income countries with many people employed by travel and tourism. The resilience of destinations is conditioned by factors such as the local policy environment, public health policies, ICT readiness, government policies for tourism, and the extent of tourist service infrastructure. In this respect, operators in many developing countries are likely to be more vulnerable than operators in developed countries. Finally, countries with substantial domestic tourism markets or which can form regional 'travel bubbles' are likely to experience quicker recoveries than those countries dependent on inter-regional markets and particularly those dependent on China, Europe and the U.S.

In responding to the pandemic, governments have employed a range of instruments to support operators in the travel and tourism sector. While some governments have provided support to firms across the economy and the tourism sector in general, others have focused policy interventions on specific tourism sub-sectors such as hospitality, food services, hotels, and airlines. While debt finance appears to be the most popular form of support among governments, other instruments employed include the easing of regulatory burdens, waiving of taxes, fees and charges, provision of cash grants and subsidies, and employment and training support. Governments should closely monitor the impact of these measures to avoid unintended consequences of support measures in the medium-term.

To both support the containment of COVID-19 and to facilitate a robust recovery of the tourism sector, this note recommends that stakeholders adopt a structured three phase approach to addressing the challenges induced by the crisis. While the virus poses a continuing threat to public health, stakeholders should initially focus on supporting measures to contain the virus and on helping viable businesses to withstand the crisis. Potential measures include carefully managing travel restrictions, providing tax rebates and fee waivers, and subsidizing training to forestall layoffs. Once the crisis subsides, stakeholders should focus on building understanding of prevailing consumer sentiment and in developing new products and modalities appropriate for the post-crisis context. For instance, stakeholders may implement periodic surveys to collect data from both providers and consumers, expand the access of small-scale providers to digital platforms, and incentivize training and upskilling. This is also a good time to consider strategic public investments in product upgrades so the destination is positioned for recovery when the time comes. As the demand for travel and tourism starts to grow again, stakeholders should develop policies and practices that enhance the resilience, and economic and environmental sustainability of the sector, such as by enhancing the efficiency and equity of regulation, investing in inclusive, eco-friendly and communitybased tourism models, and leveraging technology to enhance regulatory compliance and expand access to market for smaller operators. By taking measures to deepen the positive impacts and minimize adverse consequences, destinations can help build back a better travel and tourism sector.

As the effects of the pandemic unfold, the World Bank Group continues to monitor and advise clients on how to respond to the structural changes that are underway in the tourism sector. These include:

- Increasing focus on health and hygiene standards;

- Understanding how demand is changing (including the role of domestic and regional tourism);

- Interpreting changing business models due to consolidation and corporate restructuring;

- Mobilizing innovation and technology solutions impacting distribution and market access; and

- Guiding public investments in destinations to position them for a more sustainable and resilient tourism industry post-COVID-19.

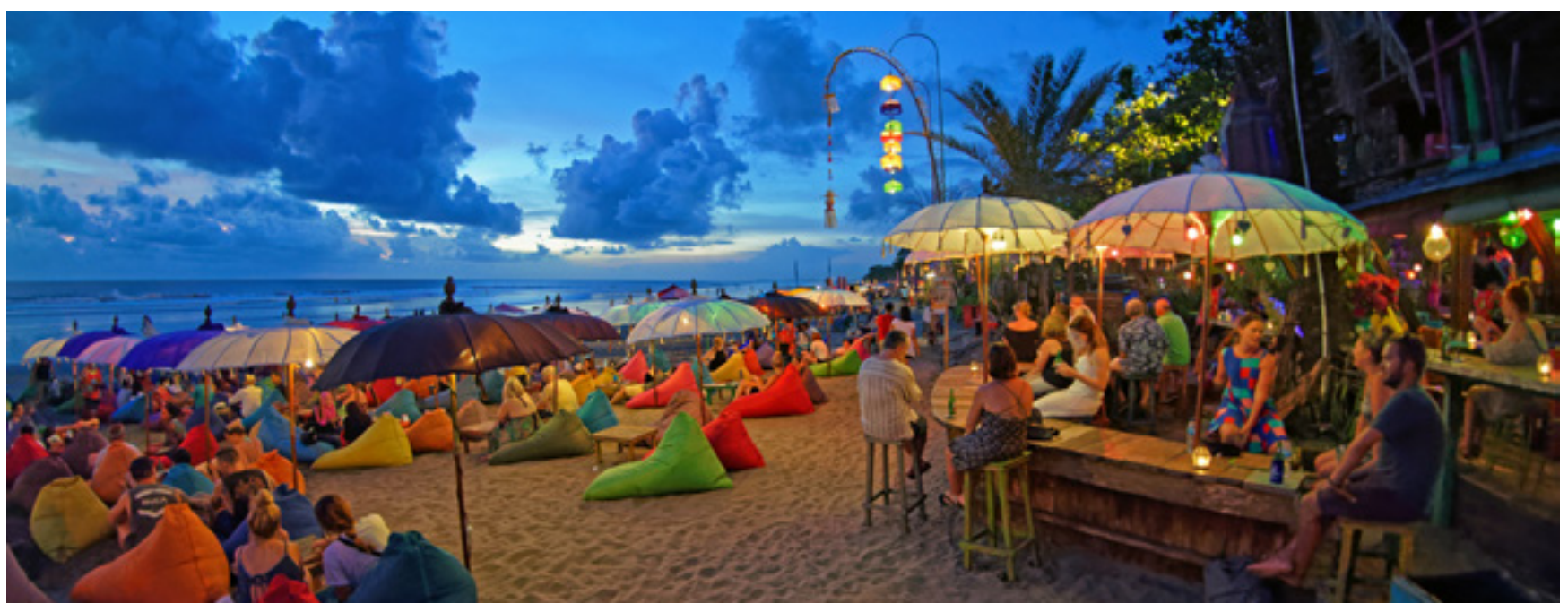




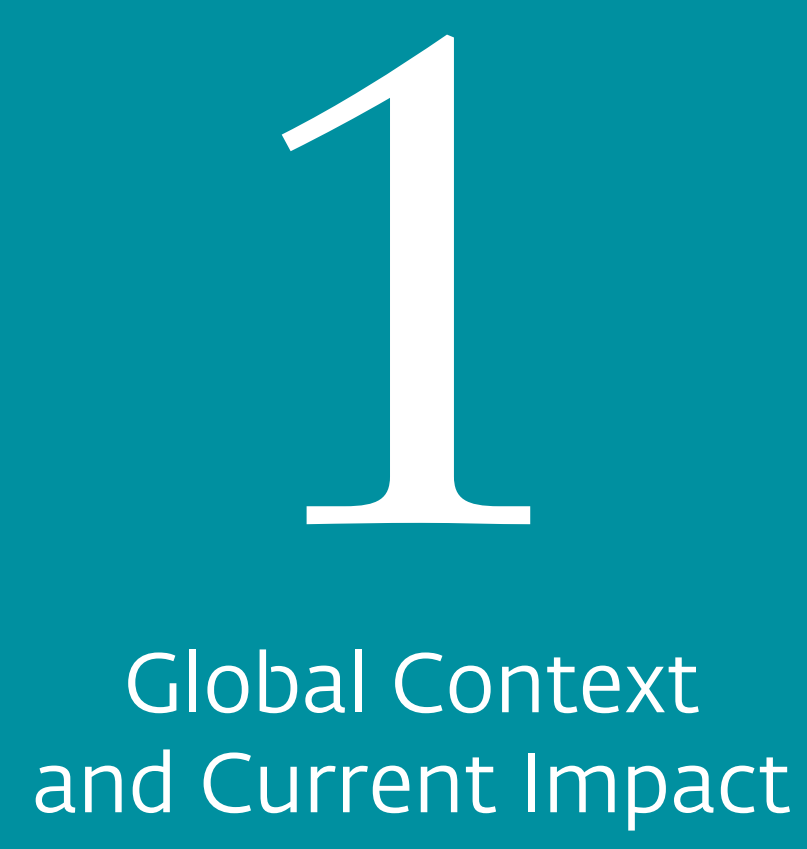

The travel and tourism industry was one of the first real sectors to be affected by COVID-19. The crisis has impacted every facet of the industry and demonstrated the vulnerability of the sector's vast value chain. Since 2000, global travel and tourism revenues have nearly tripled with the sector now contributing 10.4 percent of global Gross Domestic Product (GDP) and providing one out of 10 jobs worldwide. As of mid-April 2020, international travel has ground to a halt. The World Travel and Tourism Council (WTTC) estimates global travel could shrink by more than 30 percent in 2020. According to the United Nation World Tourism Organization (UNWTO), 100 percent of destinations have some level of travel restrictions in place, with 72 percent of countries completely stropping international travel. ${ }^{1}$ Increasingly, countries are discouraging both international and domestic travel. Latest figures from WTTC show that globally 100 million jobs are at risk in the sector with a potential global loss of up to $\$ 2.7$ trillion in $2020 .^{2}$ 
The economic crisis triggered by COVID-19 will impact large and small businesses alike. Many will not survive an uncertain timeline without an income and a likely long recovery period. Zurab Pololikashvili, Secretary-General of the UNWTO, stressed that "small and medium-sized enterprises make up around 80 percent of the tourism sector and are particularly exposed with millions of livelihoods across the world, including within vulnerable communities, relying on tourism." The economic shock could affect small and medium businesses relatively more as they do not have the capacity, cash flow, diversity of markets or supply chains, and resources to mitigate impacts. ${ }^{3}$

Global businesses across the tourism value chain have paused operations including airlines, accommodation providers, cruise lines, and tour operators and are already experiencing major immediate impacts. A report by CAPA - Centre for Aviation suggests that many airlines will be driven into technical bankruptcy by the end of May. ${ }^{4}$ Air Canada and Qantas have scheduled the grounding of all international flights with more airlines to follow suit on a daily, if not hourly, basis. British Airways, Virgin Atlantic, Ryanair, and others, have dramatically scaled back their operations, cancelled routes, and grounded many planes. Most of the major hotel brands have withdrawn their 2020 forecasts, with the American Hotel and Lodging Association estimating that the hotel industry in the United States is losing $\$ 3.5$ billion in revenue weekly since the beginning of the crisis. ${ }^{5}$ On April 9, the Centers for Disease Control and Prevention, the national public health institute of the United States, renewed a no sail order on all cruise ships that operate in United States waters. The order will be in place until COVID-19 is no longer an emergency. ${ }^{6}$
The Cruise Lines International Association (CLIA) estimates that if the order were to remain in effect for a year, the measures could generate losses of $\$ 51$ billion and 173,000 direct and 343,000 total jobs in the United States alone. This is likely to have a significant impact on the $\$ 150$ billion global industry. The three major cruise companies - Carnival Corporation, Royal Caribbean International, and Norwegian Cruise Lines - have already seen a 70 to over 80 percent drop in stock prices. ${ }^{7}$ TUI Group, Europe's largest package holiday tour operator, and Intrepid Group, one of the largest adventure tourism companies, have both suspended all international package holidays, severely impacting their business as well as the viability of thousands of local SMEs in their supply chains.

Compared to the earlier epidemics, the impact of COVID-19 on the tourism sector will be significantly different. While this global pandemic is far greater than the SARS outbreak, there are three other major differences. First, travel has grown rapidly since the early 2000s when SARS hit, with international arrivals more than doubling between 2000 and 2019. China, a large part of that growth, is now the largest outbound tourism market. Secondly, the emergence of social media as a means of sharing information is compounding uncertainty and has led to heightened anxiety in relation to travel. ${ }^{8}$ This is likely to continue into the recovery period. Thirdly, the median age of the global population is higher than ever before. This means there is a larger, older population that is more at risk. In 2018, for the first time in history, the number of people over the age of 64 was higher than the number of children under the age of five. ${ }^{9}$

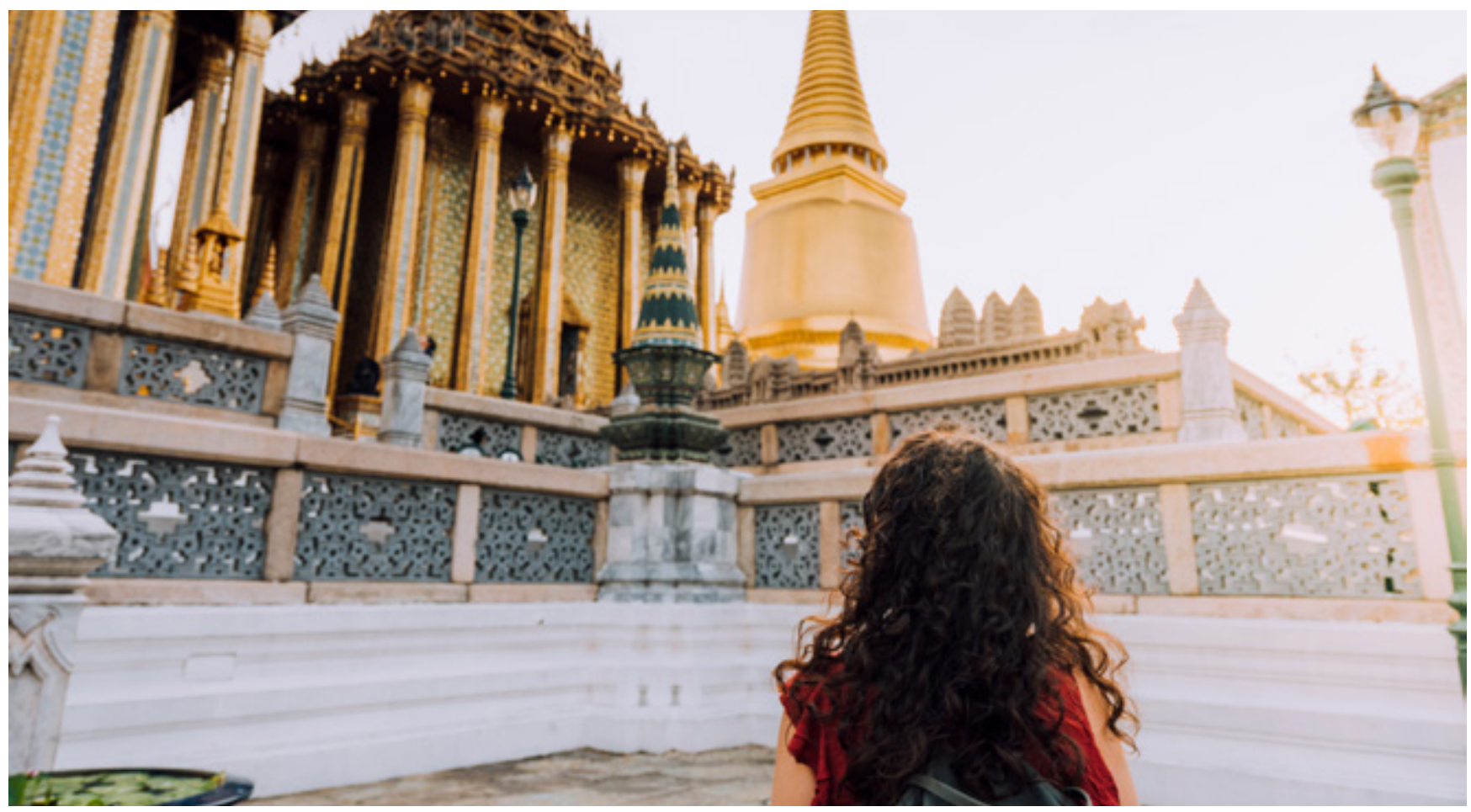




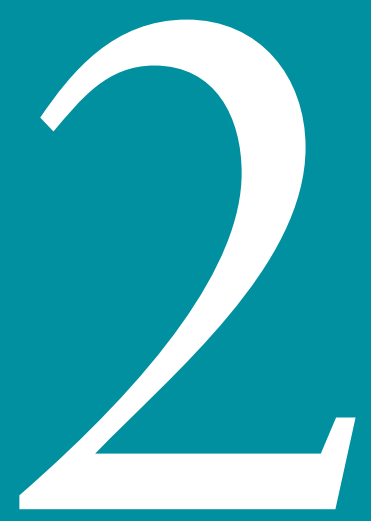

\section{Sector Impacts and Country Vulnerabilities}

As travel and tourism declines, it will impact both the demand and supply sides, affecting the entive tourism ecosystem. The immediate and severe demand shock of total travel bans and border closures during the crisis has caused a contraction of the industry. In the recovery period, when travel bans are lifted, demand may be slow to recover as the crisis may trigger a global recession with millions losing their jobs and spending abilities. Supplyside effects will vary across the value chain. This will depend on the scale of operations, exposure to more vulnerable demand segments (such as older populations, source markets with the highest economic impact, and others) and the financial strength of individual operators including their ability to weather the impact of substantially reduced cash flow. Countries will also be affected differently depending on their economic dependence on tourism and overall capacity to recover after the crisis. 
The COVID-19 crisis may have long-term impacts on the travel and tourism industry. The industry - spanning airlines, bus and train companies, cruise lines, hotels, restaurants, attractions, travel agencies, tour operators, online travel entities, and others - has entered a state of suspended animation due to the current pandemic. Given the narrow margins and low cash reserves that characterize the industry, many companies across the subsectors are likely to fail in the absence of external support to reschedule or defer debt payments and other running costs, ultimately leading to unemployment. This pandemic may also lead to substantial consolidation of many aspects of the industry. Depending on the nature, scope, and severity of the pandemic, the economic and psychosocial impacts are likely to curb the demand for travel and tourism services for many months — and potentially years — following the crisis.

Longer-term effects of the crisis can impact consumer demand for travel and tourism services on several levels. These include broad economic effects and psychosocial impacts.
If, as expected, the pandemic causes a global recession and high levels of unemployment, demand for travel and tourism services will be suppressed by a downturn in disposable income and lower levels of business activity. The crisis is also likely to make consumers more tentative about travel as they will tend to associate travelling and tourism with higher risks of contracting COVID-19. Against this backdrop, government efforts will be critical to stimulate demand, enabling the industry to recover.

\section{Sector Impacts}

As a cross-cutting industry, the tourism sector value chain touches almost all aspects of a country's economy. There are several channels through which the impacts will be felt the deepest. Figure 1 shows the extensive supply-side channels which are being affected.

Figure 1. Tourism Product Distribution Channels

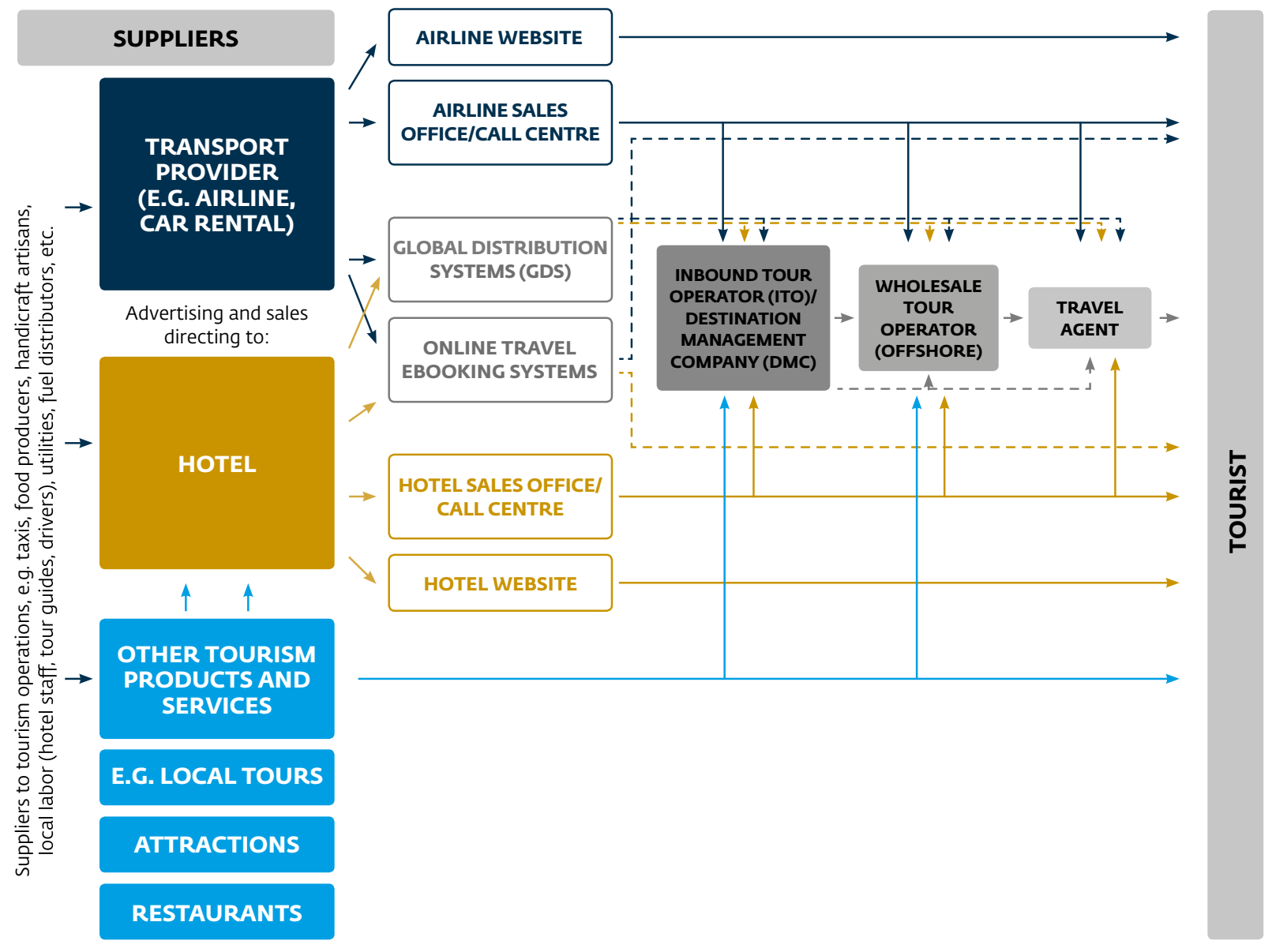

Source: Tourism for Development: Tourism Diagnostic Toolkit (World Bank, 2019). 
The current situation is outlined below along with possible implications for select industries comprising the tourism value chain.

\section{Aviation}

Worldwide passenger flights have fallen precipitously across all regions over the past three months (Figure 2 and Appendix 1). According to an analysis of data provided by FlightRadar24, passenger flights during the week of June 8-15 were a quarter of the volume during the corresponding week in 2019 (year-on-year). International flights have taken the greatest hit. The steepest declines have been registered in Sub-Saharan Africa, Europe and Central Asia, Latin America and the Caribbean, South Asia, North Africa and the Middle East, with North America and East Asia and the Pacific recording shallower - albeit still severe - declines.

Figure 2. Change in Total Passenger Flight Arrivals per Region

Year-on-year change in weekly passenger flight volume (2019-2020)

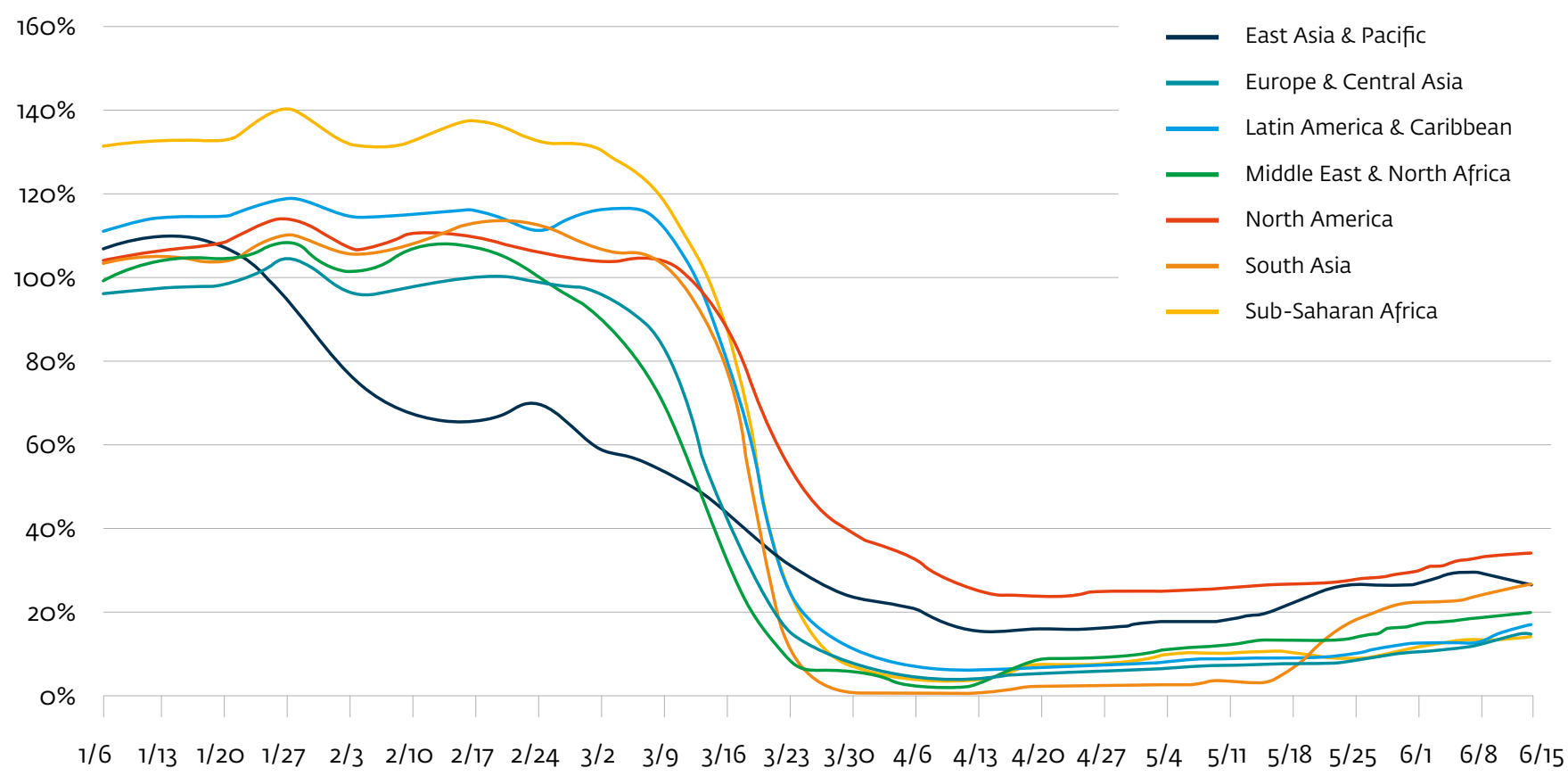

Source: ETIMT Analysis using FlightRadar24 Data.

Worldwide forward travel bookings have started to pick up in early May, but nonetheless remain at historic lows. As of June 22, scheduled flights worldwide are down 63 percent on a year-on-year basis. The Chinese aviation market has rebounded somewhat, with a drop of 24 percent year on year. Other major markets, such as Spain, Germany, Singapore, France, and the U.K., report decreases in excess of 80 percent. ${ }^{10}$ The International Air Transport Association (IATA) expects the effects of the crisis to last well into 2021, estimating that passenger air travel, as measured by revenue passenger kilometers, will remain 32-41 percent below expected levels in $2021 .^{11}$

IATA estimates that, on average, airlines had two months of cash on-hand at the start of this year (Figure 2). This level was already below the three months average level considered to be a reasonable buffer. Airlines in the United States and Europe are facing particularly severe cash flow pressure. Due to the limited extent of cash balances, IATA advises that airlines will "need to draw on credit lines or find other means of support during this crisis period". ${ }^{12}$ 
Figure 3. Airlines' Balance Sheet Liquidity (Cash and Equivalents Coverage of Revenues*)

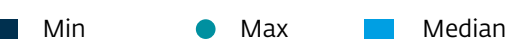

Months

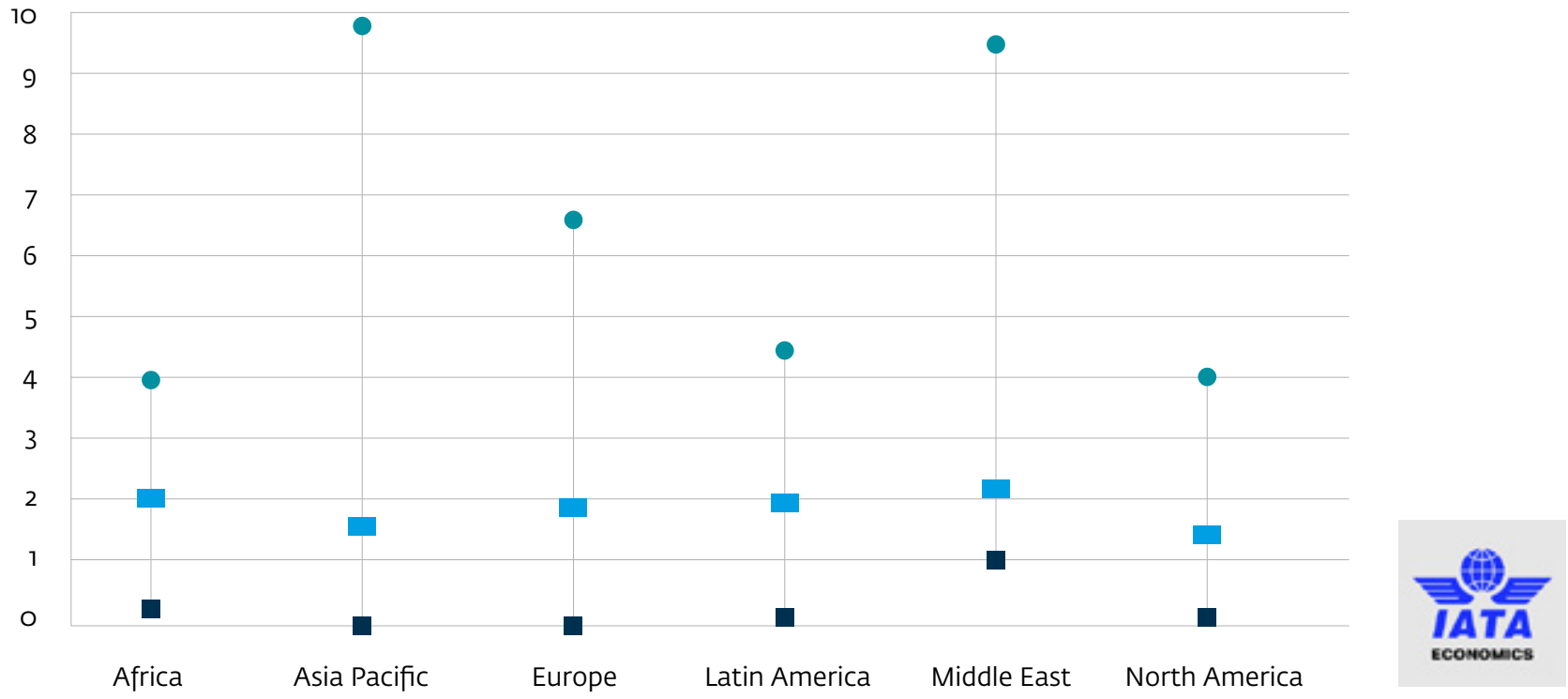

*Latest available 12 months cumulative revenues at March 2020.

Africa, Latin America and the Middle East might not be representative due to small sample size.

Source: IATA Economics using the Airline Analyst.

While there will be heterogenous effects, analysts estimate that COVID-19 will severely affect the viability of many airlines in the world. ${ }^{13}$ Vulnerability of airlines to total collapse will vary based on a variety of factors. Airlines in developed countries with excess cash balances or access to discounted rates of credit will be better positioned. Likewise, airlines that are state-owned (as is the case with major airlines in China and the Middle East), privately-owned 'flag carriers', or large private airlines with a high proportion of unionized labor (such as the 'big three' in the U.S.), face a relatively high probability of surviving the crisis. Privatelyowned airlines, particularly those in developing countries, and budget carriers that operate on narrow margins and are highly dependent on leisure travel, are extremely vulnerable. Similarly, state-owned carriers in developing countries are in a precarious position. As of mid-May, airlines that had either gone into bankruptcy, administration, or sought protection include South African Airways, Avianca, Air Mauritius, Virgin Australia, and Air Deccan. ${ }^{14}$

The collapse of individual airlines will, in turn, have damaging consequences for jobs and market dynamics across the value chain. This will be the case for those employed by companies serving both airlines, airline employees, and airline passengers
- such as catering, maintenance, hotels, and travel agents. The aviation industry and those it employs are likely to suffer long-lasting impacts as a result of the pandemic. This could lead to a process of consolidation across the industry such as occurred in the United States after 9/11 and the 2008 Global Financial Crisis (GFC). ${ }^{15}$

In the wake of the pandemic, the economic and psychosocial impacts will potentially suppress demand for aviation for many months. The low level of demand is likely to be partially offset by cheap operating costs due to low oil prices, a glut in aircraft due to excess capacity, low costs of financing, and low labor costs. If external measures to stimulate demand for travel services are forthcoming, it is feasible that investments made by new and existing operators responding to the low level of operating costs could expedite the industry's rebound. However, if external support is not forthcoming and/or if the response in consumer demand is muted, it is feasible that the scope of the industry could be significantly smaller in the years following the pandemic than immediately prior to the crisis. In those developing countries where governments lack the capacity to extend financial support to operators, the aviation sector could be substantially smaller in the wake of the crisis than prior to it. 


\section{Accommodation and Lodging}

Hotel revenues have collapsed. Marriott, one of the world's largest hotel companies with 1.4 million rooms worldwide, has reported that quarterly revenue losses are worse than those experienced during 9/11 and GFC combined. Quarterly revenues are down 75 percent in most markets, compared with 25 percent - the largest quarterly drop - in the earlier crises. According to the American Hotel and Lodging Association (AHLA), as of April 15, nearly 80 percent of hotel rooms were closed and hotel occupancy rates were below 20 percent. ${ }^{16}$ In India, large-scale cancellations spiked across the corporate, Meetings, Incentives, Conferences and Events (MICE), and leisure segments in March. According to $\mathrm{STR},{ }^{17}$ the hotel industry in all world regions had recorded large double-digit declines in global revenues per available room (RevPAR) by March, with Asia (negative 67.8 percent) and Europe (negative 61.7 percent) posting the biggest decreases. According to a leading industry expert, bookings have "dropped off a cliff across the board." 18

Hotels will not be able to sustain this level of revenue loss over time as continuing to operate may risk a hotel's ability to permanently reopen, with significant impact on job losses. Thus, many hotels will close with immediate job losses. One operator in the United States with 13,000 rooms has laid off over half of its 8,000 employees and had planned to lay off a further 2,000 by the end of April. Based on current occupancy estimates, AHLA estimates that a total of four million jobs have either already been eliminated across the United States or will be lost by the end of May. While data on job losses are more scarce for emerging economies, STR notes that Colombia, Argentina, and Brazil are the three Latin American countries most affected by COVID-19 with occupancy rates declining by 74 percent to 93 percent on the week of March 30, 2020. ${ }^{19}$ In Bogota alone, daily occupancy rates dropped from 78 percent on February 19 to 3.9 percent on March 29.

The hospitality industry is already facing widespread closures, bankruptcies, and layoffs, and the situation is likely to worsen in the coming months. Widespread redundancies can be expected among employees of hotels and other hospitality service providers unless wage subsidies, blanket moratoriums or deferment of debt payments, and tax holidays can be instituted quickly. Tourism and hospitality investors may also incur large losses. ${ }^{20}$ Operators, who are unable to access flexible lines of credit and/or other forms of support, will be particularly vulnerable to bankruptcy and closure. Small- and medium operators, which dominate the hospitality sector in many developing countries, will be especially hard hit.
As the pandemic will lead to bankruptcy and closure of many of the industry's smaller operators, consolidation of the sector can be expected to occur in the wake of the crisis. In addition to lower consumer demand, it is likely that price increases - following consolidation - in some destinations and segments could further dampen demand over the mediumterm. Together, this may result in an appreciably smaller sector in terms of employment and revenue than before the pandemic.

Peer-to-Peer (P2P) accommodation will be similarly impacted. However, they may recover faster due to lower operating and fewer upfront costs such as debit repayments, salaried employees, marketing expenses, and utilities. In 2017, P2P accommodation had approximately seven million beds. ${ }^{21}$ Most of these bookings are made via digital platforms such as Airbnb and Booking.com. Despite generally lower operating costs, P2P accommodations are likely to be hit just as hard with cancellations in the short-term as larger commercial accommodations. In addition, P2P owners and employees lack formal employment protections. However, once the crisis is over, this form of accommodation may bounce back faster as there are less upfront costs. Further, with the closing or bankruptcy of many commercial properties, a potential room shortage in some markets may lead to higher-than-normal occupancies in P2P properties. For example, in St. Maarten, following Hurricane Irma, when most commercial properties were not usable, P2P accommodation grew both formally and informally. With this in mind, governments with policies against such private lodging entities may need to consider temporary exemptions to enable legal growth of this largely undocumented sector.

\section{Tour Operators}

As travel demand declines, tour operators globally are going through an unprecedented stress test. Most tour operators have developed relaxed booking policies to encourage future holiday bookings during the COVID-19 crisis. Tour operators including Kuoni, Hayes \& Jarvis, Prestige, G Adventures, i-escape, On Foot Holidays, and Camino Ways are among those waiving fees if clients want to change travel destinations or trip dates. As commercial airlines ground more flights and countries close borders to outbound and inbound travel, bookings will go down to zero.

Given that small and medium enterprises make up 80 percent of the industry, the worst-affected tour operators will be the smaller companies operating in more vulnerable emerging economies where international long-haul travel is a significant market segment. Below is an example from a tour operator in Tanzania, handling roughly 30,000 passengers per annum:22 
Box 1. Example of COVID-19 Impact on a Tour Operator in Africa

- We expect to lose 27 percent in the first three months, stretching to 66 percent after 6 months.

- The key months will be July and August. If travel does not restart by then, the consequences will be ultimately terminal for all but a few operators.

- The VAT cost to government is 18 percent of revenue.

- It is difficult to predict the park fee and concession fee revenue for the government but it is around 10 percent of our revenue plus the associated VAT.

- Our best-case scenario is a six-month wage cut, which amounts to US\$500,000, with associated loss of government taxation of around US\$230,000.

- We are likely to incur job losses of over 20 percent if travel picks up before August and 50 percent if it is postAugust.

- Supplier costs would fall in line with our revenue as Gross Profit is relatively consistent and KPIs are driven by the number of passengers.

- Guides and small safari operators who rely on seasonal work would lose out to in-house guides on payroll.

- Associated industries such as vehicle workshops, office support services, town transfers, and local single-family businesses would fall as Arusha is the safari capital.

\section{Cruise Operators}

The cruise sector is dominated by three global companies - Carnival Corporation, Royal Caribbean Cruises, and Norwegian Cruise Line - that own 18 of the world's cruise line brands. In 2018, the cruise sector provided 1.177 million jobs equating to $\$ 50.24$ billion in wages and salaries and $\$ 150$ billion in total output worldwide. Cruising has been growing rapidly with cruise lines investing in bigger ships, reaching capacities never before handled. As forecasted by Cruise Lines International Association, 32 million passengers were scheduled to travel on 278 cruise line ocean ships in 2020. Regionally, the Caribbean and Mediterranean see the highest percentage of cruises with 32 percent and 17 percent of all cruise line deployments, respectively. ${ }^{23}$ In some countries, the cruise sector is a major contributor to the economy and the foundation of the tourism sector. Some countries in the Pacific are particularly dependent on the cruise sector, like Vanuatu that received \$34.6 million in direct economic impact in 2014. ${ }^{24}$

Cruise lines have been at the frontline of the COVID-19 crisis playing an inadvertent role in the global spread of the pandemic. Between February and March 2020, there were major outbreaks on multiple cruise ships: The Diamond Princess, which was quarantined in the port of Yokohama, Japan; the Grand Princess cruise ship off the coast of California; and at least 25 additional cruise ships leading to 800 confirmed cases among passengers and crew. ${ }^{25}$ With a high passenger density the largest ship, Symphony of the Seas, carries 6,680 passengers - the cruise sector is particularly at risk for the spread of COVID-19. Further, it brings together diverse markets from around the world, and a high percentage of the market is older adults over the age of 65 , who are at higher risk.

The Cruise Lines International Association, representing 50 cruise lines, took the first step and announced a temporary suspension all cruise operations at least till the end of May. This was shortly followed by the United States Center for Disease Control no sail order announcement for all cruise ships over 250 passengers until further notice. ${ }^{26}$ While the dates vary with each company, only a few estimate resuming operations in June - Carnival Corporation (August 1), Royal Caribbean Cruises (June 12 at the earliest), MSC Cruises (July 10), Viking Cruises (June 30) and Norwegian Cruise Lines (June 30) - and even these dates are tentative. Companies are taking different approaches to staff layoffs during this time. Viking Cruises and Disney Cruises will continue to compensate both shoreside staff and crew for a few months; Princess Cruises maintained shoreside employees while shipboard crew were sent home. ${ }^{27}$ Since approximately one third of all cruise employees worldwide are from the Philippines, employment loss will have a disproportionate impact on the country. ${ }^{28}$

The three major cruise companies - Carnival Corporation, Royal Caribbean International, and Norwegian Cruise Lines - have already seen major drops in stock prices with Norwegian Cruise Lines experiencing around an 80 percent drop since the beginning of the year. The negative shock on stock prices, reputational damage caused by COVID-19, and registration under foreign flags will impact the ability of cruise companies to mobilize capital in the short-term to cover costs. In March, Carnival Corporate had an active cash burn of $\$ 500$ million per month and required an injection of $\$ 6$ billion to weather the crisis. With its headquarters in the United States, Carnival's ships, like most other major cruise ships, sail under foreign flags in tax haven countries with weaker employment rules. This has excluded them from the United States stimulus package. Instead, they will be looking to mobilize capital through secured notes, convertible notes, and issuance of new shares. ${ }^{29}$ While no reliable forecasts on the long-term impact of the crisis on the cruise sector are available, it may fuel further consolidation in the sector, an existing trend over the last two decades. Alternatively, it could lead to increasing market share for smaller ships, which offer higher quality and lower density cruises. In the short-term, discussions on supporting the industry highlight how this crisis provides an opportunity to increase the sector's environmental sustainability and support more sustainable labor practices. 


\section{Digital Platforms}

Bookings across the tourism sector are driven by technology platforms including those that service travel agents such as global distribution systems (Sabre, Amadeus, Galileo), and those that cater to independent travelers booking directly (Booking.com, TripAdvisor, Airbnb, Expedia, Travelocity). Prior to the crisis, Online Travel Agencies (OTAs) represented 39 percent of the United States' online travel market and were growing exponentially. TripAdvisor alone was responsible for $\$ 546$ billion (10.3 percent) of global tourism spend. An increase in TripAdvisor reviews is often followed by a higher tourism demand. ${ }^{30}$

Three main business models predominate among OTAs, increasing their resilience. The bulk of TripAdvisor revenues are based on advertising and a pay-per-click revenue model. Booking.com (owned by the Priceline Group), on the other hand, is driven largely by a commission model, while Expedia mainly buys services in advance and in bulk before selling them to consumers. While companies like Priceline and Expedia are well capitalized and likely to recover more quickly, They have suffered large losses and there have been substantial losses of jobs. ${ }^{31}$ Most OTAs have withdrawn their 2020 forecasts and Expedia expects the negative impact to be $\$ 30-40$ million or higher in the first quarter of $2020 . .^{32}$ The recovery of these digital platforms will be important for tourism SMEs, which rely on OTAs and digital distribution channels as a key part of their business models.

OTAs by their nature are more agile in responding to emerging data and shifting supply. They will be faster to bounce back compared to stuck-in-place service providers constrained by their locational circumstances. Brand and brand loyalty are the primary concerns of these OTAs as they navigate the crisis. They want to retain customers as well as be the platform of choice post-crisis.

\section{Global Distribution Systems}

A handful of companies are the foundation of booking management for travel agents globally. Sabre, Amadeus, Galileo, and Apollo are Global Distribution Systems (GDS). These reservation systems serve as marketplaces for travel agents to reserve airlines, hotels, and other travel services. They act as a global inventory management and reservation system. While most travelers never interface with these businesses, they are a critical element of any booking made through a travel agent or tour operator. As an indication of the impact on GDS, Sabre plans to make $\$ 200$ million in cost reductions this year including a temporary reduction in pay for US-based salaried workforce, CEO pay cut, and a reduction of benefits, among other actions. Additionally, the company will suspend the payment of quarterly cash dividends on common stock. ${ }^{33}$

\section{Other Sectors and Impacts on Global Value Chains}

The impact of disruptions caused by COVID-19 in the tourism and travel industry goes well beyond the sector, affecting many other Global Value Chains (GVCs). The more obvious are the suppliers to the industry - food services, furniture suppliers, property management services, and event organizers. As an example, the cancellation of the Mobile World Congress in Barcelona in February had an estimated loss of €479 million and 14,000 jobs, covering diverse areas including architects, ICT, audiovisual, and logistics. ${ }^{34}$ The impact has been significant on the restaurant industry as well. Globally, restaurants started to record a decline in reservations in late February, plummeting to zero by mid-March. There has been some recovery in recent weeks reflecting divergent reopening policies across countries. While some restaurants have been able to shift their operations to takeout and delivery models, the impact on the industry is severe.

\section{Figure 4. Restaurant Reservations - Decline in Year-on-year Reservations}

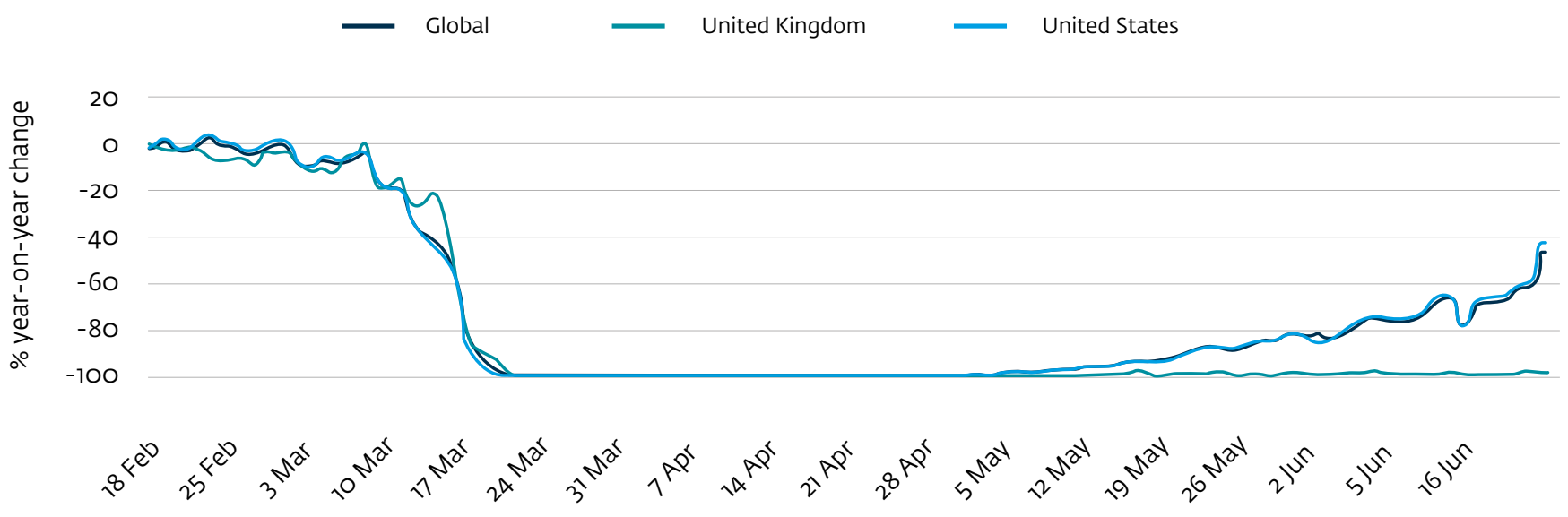

Source: ETIMT Analysis using OpenTable database. 
The declining demand is also affecting the transport industry GVCs, especially aircraft and automotive supplies. The aircraft industry is ending its 16-year surge (since the end of SARS). Many airlines including Cathay and Norwegian have put their orders on hold, shares for Boeing and Airbus have fallen to 1987 levels, and Boeing has drawn a $\$ 13.8$ billion loan to face the crisis. ${ }^{35}$ In the automotive industry, the motor-coach industry has dropped radically - between 60 percent for scheduled and 95 percent for charter in the United States ${ }^{36}$ - affecting producers of the buses. These drops in demand are independent of the fact that many are closing their plants due to supply chain disruptions or quarantine requirements.

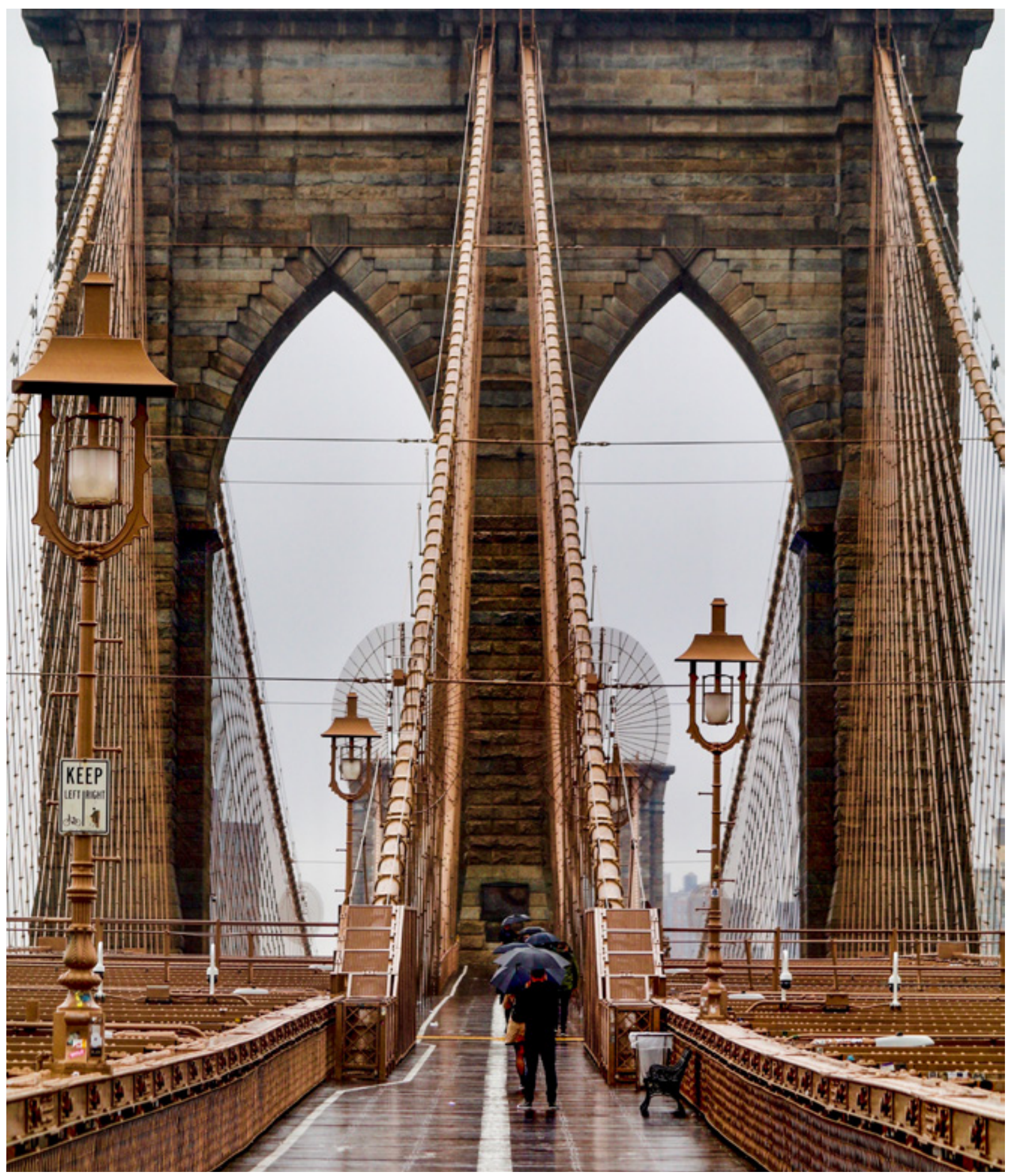




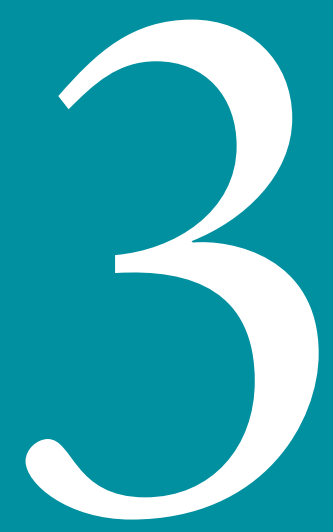

\section{Country Impacts and Vulnerabilities}

The question of which countries will be the hardest hit, and which will recover first is critical for response planning. While all countries will be impacted by the COVID-19 crisis, the extent of that impact will depend on i) the degree of dependence of the country's economy on tourism and tourism-related services and suppliers; ii) the supply-side resilience of the country -- its ability to respond and recover from the crisis; and iii) the demand dynamics - resilience of the country's key tourism source markets. Accordingly, the MÆT Global Tourism Team has conducted analysis on the first two of these areas: dependency and resilience. The purpose of these analyses is to identify which regions and countries are likely to be the hardest hit by a decline in travel and tourism and which are likely to find it hardest to recover and may need more support. The dependency analysis uses 2019 World Travel and Tourism Council (WTTC) ${ }^{37}$ data on the total contribution of travel and tourism to GDP and to employment, with data for 177 countries. Supply-side tourism resiliency is assessed using 45 indicators from the 2019 World Economic Forum Travel and Tourism Competitiveness Index (WEF TTCI). ${ }^{38}$ For demand-side resilience, there are still high levels of uncertainty given that the timeline for travel demand recovery will likely be driven by advances in medicine and healthcare-related policies. However, a key issue to note is that uncertainty is a constant in both supply and demand sides, creating a complex situation in which agility and availability of data is critically important. 


\section{Tourism Dependence}

Over 40 percent of countries relied on travel and tourism for more than 10 percent of their GDP and employment in 2019 according to WTTC.

- There are 76 countries with more than 10 percent of their GDP from travel and tourism; 19 of these are low and lower-middle income countries.

- Globally, the countries that most rely on travel and tourism are the small island countries (by GDP in 2019). There are 16 small island countries with more than 30 percent of their GDP from travel and tourism: Antigua and Barbuda, Aruba, the Bahamas, Barbados, Belize, ${ }^{39}$ British Virgin Islands, Cabo Verde, Dominica, Fiji, Grenada, Jamaica, Macao, the Maldives, Seychelles, St. Lucia, and Vanuatu.

- In terms of employment, the patterns are similar. In 79 countries, more than 10 percent of employment is attributed to tourism; 17 of these are low or lower-income countries.

The table that follows shows all 177 countries in the WTTC GDP dataset categorized by their degree of economic dependence on tourism (see Appendix 2 for further details). The results are divided into four categories of dependence: severe, high, medium, and low. Regionally, Latin America and particularly the Caribbean, Europe and Central Asia, East Asia and the Pacific have the highest number of severely tourism dependent countries. While these countries' economies will be most impacted by COVID-19, the economic impact on small islands, across all regions, is likely to be the worst because of low economic diversification of their economies.

\section{Table 1. Tourism Dependency by Tourism contribution to GDP, WTTC 2019 (country names)}

\begin{tabular}{|c|c|c|c|c|}
\hline Region & $\begin{array}{l}\text { Severe }=\geq 20 \% \text { GDP } \\
\text { in tourism }\end{array}$ & $\begin{array}{l}\text { High }=10-20 \% \text { GDP } \\
\text { in tourism }\end{array}$ & $\begin{array}{l}\text { Medium = 5-9\% GDP } \\
\text { in tourism }\end{array}$ & $\begin{array}{l}\text { Low }=55 \% \text { GDP } \\
\text { in tourism }\end{array}$ \\
\hline $\begin{array}{l}\text { East Asia } \\
\& \text { the } \\
\text { Pacific }\end{array}$ & $\begin{array}{l}\text { Cambodia, Fiji, Macao SAR, } \\
\text { Philippines, Vanuatu }\end{array}$ & $\begin{array}{l}\text { Australia, China, Hong } \\
\text { Kong SAR, Malaysia, } \\
\text { New Zealand, Singapore, } \\
\text { Solomon Islands, Tonga, } \\
\text { Thailand, Kiribati }\end{array}$ & $\begin{array}{l}\text { Brunei Darussalam, Indonesia, Japan, } \\
\text { Vietnam, Lao PDR, Mongolia }\end{array}$ & $\begin{array}{l}\text { Rep. of Korea, Papua } \\
\text { New Guinea, Myanmar }\end{array}$ \\
\hline $\begin{array}{l}\text { Europe \& } \\
\text { Central } \\
\text { Asia }\end{array}$ & $\begin{array}{l}\text { Albania, Croatia, Georgia, Greece, } \\
\text { Iceland, Montenegro }\end{array}$ & $\begin{array}{l}\text { Armenia, Austria, } \\
\text { Bulgaria, Cyprus, } \\
\text { Estonia, Italy, Portugal, } \\
\text { Slovenia, Spain, Turkey }\end{array}$ & $\begin{array}{l}\text { Azerbaijan, Belarus, Bosnia and } \\
\text { Herzegovina, Czech Republic, Denmark, } \\
\text { Finland, France, Germany, Hungary, } \\
\text { Kyrgyz Republic, Ireland, Kazakhstan, } \\
\text { Latvia, Lithuania, Luxembourg, } \\
\text { Moldova, North Macedonia, } \\
\text { Netherlands, Norway, Romania, Serbia, } \\
\text { Slovak Republic, Sweden, Switzerland, } \\
\text { Tajikistan, Ukraine, United Kingdom, }\end{array}$ & $\begin{array}{l}\text { Belgium, Ireland, } \\
\text { Poland, Russia, Poland, } \\
\text { Uzbekistan }\end{array}$ \\
\hline $\begin{array}{l}\text { Latin } \\
\text { America } \\
\text { \& the } \\
\text { Caribbean }\end{array}$ & $\begin{array}{l}\text { Antigua and Barbuda, Aruba, } \\
\text { Bahamas, The, Barbados, Belize, } \\
\text { British Virgin Islands, Cayman } \\
\text { Islands, Dominica, Grenada, Jamaica, } \\
\text { St. Kitts and Nevis, St. Lucia, St. } \\
\text { Vincent and the Grenadines }\end{array}$ & $\begin{array}{l}\text { Chile, Costa Rica, Cuba, } \\
\text { Dominican Republic, } \\
\text { El Salvador, Honduras, } \\
\text { Mexico, Nicaragua, } \\
\text { Panama, Uruguay }\end{array}$ & $\begin{array}{l}\text { Argentina, Bolivia, Brazil, Ecuador, } \\
\text { Guatemala, Haiti, Peru, Trinidad and } \\
\text { Tobago, Venezuela }\end{array}$ & $\begin{array}{l}\text { Colombia, Guyana } \\
\text { Paraguay, Puerto Rico, } \\
\text { Suriname }\end{array}$ \\
\hline $\begin{array}{l}\text { Middle } \\
\text { East \& } \\
\text { North } \\
\text { Africa }\end{array}$ & & $\begin{array}{l}\text { Bahrain, Jordan, Malta, } \\
\text { Lebanon, Morocco, } \\
\text { Tunisia, United Arab } \\
\text { Emirates }\end{array}$ & $\begin{array}{l}\text { Algeria, Egypt Arab Rep., Iran } \\
\text { Islamic Rep., Iraq, Israel, Kuwait, } \\
\text { Oman, Qatar, Saudi Arabia, Syrian } \\
\text { Arab Republic, Yemen Rep. }\end{array}$ & Libya \\
\hline $\begin{array}{l}\text { North } \\
\text { America }\end{array}$ & & Bermuda & Canada, United States & \\
\hline South Asia & Maldives & Sri Lanka & India, Nepal, Pakistan & Bangladesh \\
\hline $\begin{array}{l}\text { Sub- } \\
\text { Saharan } \\
\text { Africa }\end{array}$ & $\begin{array}{l}\text { Cabo Verde, Sao Tome and } \\
\text { Principe, Seychelles }\end{array}$ & $\begin{array}{l}\text { Botswana, Comoros, Cote } \\
\text { d'Ivoire, The Gambia, } \\
\text { Lesotho, Madagascar, } \\
\text { Mauritius, Namibia, } \\
\text { Rwanda, Tanzania }\end{array}$ & $\begin{array}{l}\text { Benin, Cameroon, Central African } \\
\text { Republic, Ethiopia, Ghana, Kenya, } \\
\text { Malawi, Mali, Mozambique, Niger, } \\
\text { Senegal, South Africa, Sudan, Eswatini, } \\
\text { Togo, Uganda, Zambia, Zimbabwe }\end{array}$ & $\begin{array}{l}\text { Angola, Burkina Faso, } \\
\text { Burundi, Chad, Congo } \\
\text { Dem. Rep., Congo } \\
\text { Rep., Gabon, Guinea, } \\
\text { Nigeria, Sierra Leone }\end{array}$ \\
\hline
\end{tabular}

Notes: Shading indicates countries most heavily dependent on tourism. 
While generally tourism's contribution to GDP and to total employment is correlated, there are some countries that rely heavily on tourism for job creation, despite a lower contribution of tourism to GDP. In these cases, overall impact from a reduction in travel and tourism may not be immediately obvious but will be felt later as those employed in the sector lose their jobs. Among lower and lower-middle income countries, Lao PDR, Mongolia and Indonesia fall into the medium dependency category based on tourism's contribution to GDP; however, they are in the high dependency category based on tourism's contribution to employment. Similarly, Philippines has high GDP dependency and severe employment dependency. This may be driven by lower value tourism in these countries, but a high dependency on the sector for low skilled job creation. A much larger number of upper-middle and high income countries have higher dependency on tourism for employment than for contribution to GDP due to their more diversified economies, but higher reliance on the service sector for jobs.

\section{Tourism Resilience Risk}

Tourism resilience is a factor of both supply and demand-side variables. However, given the uncertainty of post-COVID-19 tourism demand, this tourism resilience model takes a supply side approach using existing data from 135 countries compiled by the World Economic Forum's Travel and Tourism Competitiveness Index (WEF TTCI). The WEF TTCI includes 90 indicators organized into 14 pillars. This model uses just 45 of these indicators in seven pillars. These include:

- Policy environment for business. Includes 12 indicators to assess if a country's policy environment is conducive for companies to do business. A strong enabling environment is critical for fast business recovery and attracting new investment with the onset of recovery.

- Health and hygiene. Includes six indicators of health and hygiene that are essential for COVID-19 recovery, such as the number of hospital beds and physician density.

- ICT readiness. Includes eight indicators (for example, mobile subscriptions, mobile network coverage, internet use) as digital engagement is likely to be a key factor to get tourism SMEs back in operation.

- Prioritization of travel and tourism by government. Includes six indicators that demonstrate government spending and management of tourism including availability of data and brand strategy. Countries that prioritize tourism, communication, and marketing will recover faster.

- International openness. Assesses visa regulations, air transport agreements, and trade agreements. While recovering from a crisis, countries with more open entry requirements will have an advantage.

- Air transport. Includes six indicators that show seat capacity, number of airlines, and quality of airline connections. A diversity of market and air route connections will aide recovery significantly.

- Tourist service infrastructure. Includes indicators on the quality of tourism facilities and services. Destinations with high-quality tourism infrastructure and services are likely to recover sooner, as they will be able to tap into high-end traveler markets that may be the first to travel again.

Like the WEF index ${ }^{40}$ itself, the tourism resilience score was calculated as the mean score across the seven unweighted WEF pillars ${ }^{41}$ to create a Tourism Resilience Risk (TRR) or vulnerability score. The score was inverted so higher scores indicate higher resilience risk. This score was then plotted against the total tourism contribution to GDP to identify which countries' tourism sectors are most at risk and are most likely to need priority tourism support in response to the COVID-19 crisis.

As with the dependency analysis, the results are divided into four categories: severe, high, medium, and low. 'Severe risk' countries are those with the highest GDP and highest TRR score, 'low risk' countries are those with the lowest GDP dependency and lowest TRR score. Figure 5 shows the results for low and lower-middle income countries based on this supply side analysis. It should be noted that WEF data do not cover most small island countries in the Caribbean and South Pacific. A separate rating for small island countries is in progress. 
Figure 5. Low and Lower-Middle Income Countries by Combined Tourism Resilience Risk and Dependency Rating

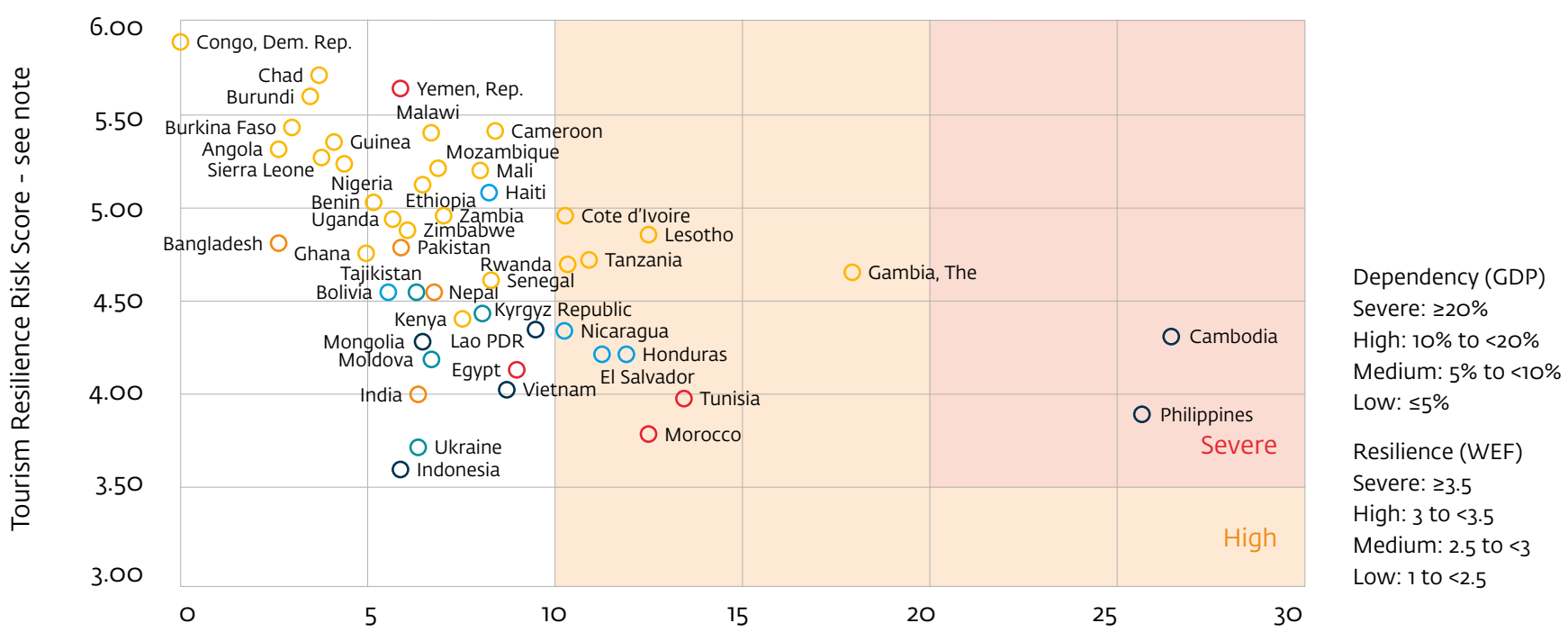

Tourism Contribution of Travel and Tourism to GDP

Note: Tourism Resilience Risk score is the mean score across seven WEF pillars inverted to identify those with the highest tourism resilience risk scores against those with the highest GDP scores, i.e. a score of $1=$ lowest tourism resilience risk and a score of $7=$ highest tourism resilience risk. To facilitate readability, axis was restricted to 2 to 6.

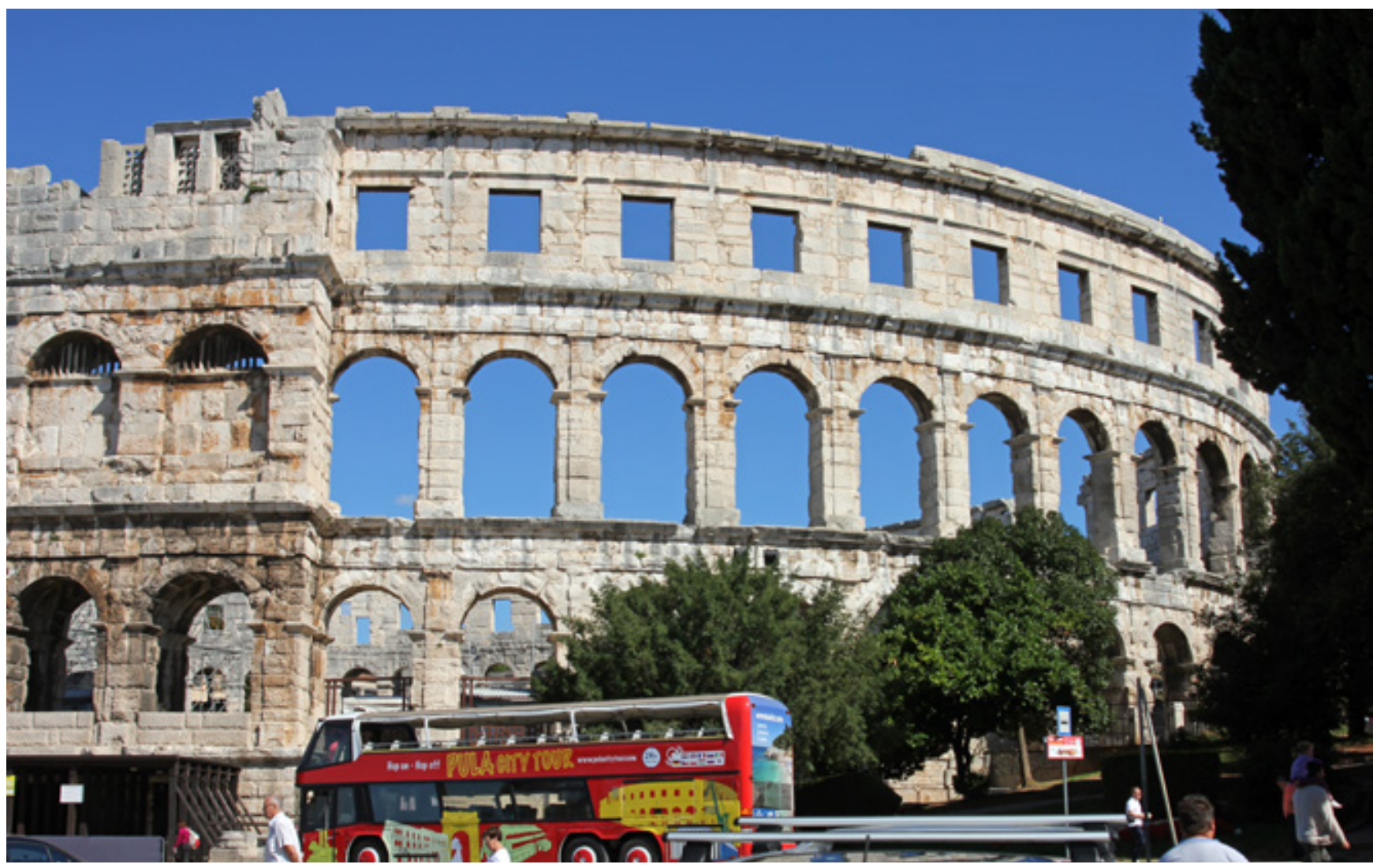


Figure 6 shows the upper-middle and high-income countries that are likely to have the most difficulty recovering (high/severe GDP and severe/high tourism resilience risk) based on this analysis.

Figure 6. Higher-middle and High-income Countries by Combined Resilience Risk and Dependency Rating

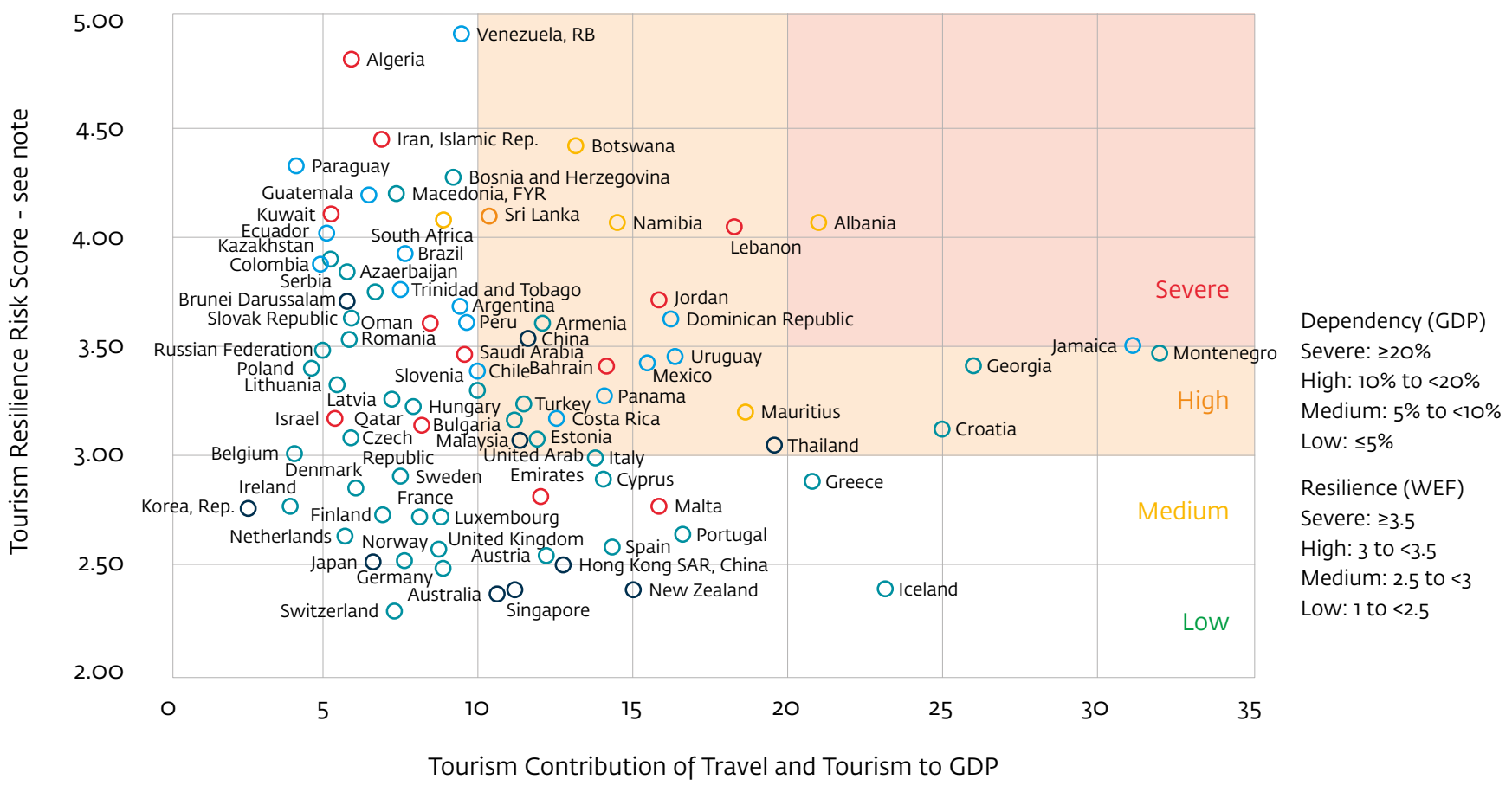

O East Asia \& Pacific $\bigcirc$ Europe \& Central Asia $\bigcirc$ Latin America \& Caribbean $\bigcirc$ Middle East \& North Africa $\bigcirc$ South Asia $\bigcirc$ Sub-Saharan Africa

Note: Tourism Resilience Risk score is the mean score across seven WEF pillars inverted to identify those with the highest tourism resilience risk scores against those with the highest GDP scores, i.e. a score of $1=$ lowest tourism resilience risk and a score of $7=$ highest tourism resilience risk. To facilitate readability, axis was restricted to 2 to 5 .

It should be noted that this analysis is based on historical supply-side data which does not include market demand, fiscal or macroeconomic factors. In some countries, international tourism is a key source of foreign exchange. The sudden and almost complete loss of foreign income can place severe constraints on a country's ability to purchase foreign goods and services. When assessing overall resilience risk for a country or destination, it will be necessary to incorporate an assessment of these factors including the scale, nature and origin of demand. The following section examines demand side factors such as the size of the domestic and intra-regional tourism market which are likely to be associated with swifter recovery.

\section{Tourism Demand Impact on Recovery}

Destinations are dependent on different source markets based on their geographic locations, access and products.
Those heavily dependent on the source markets most impacted by COVID-19 infections will impacted more severely. While constantly changing, as of mid-May, the top ten countries with the most COVID-19 cases were: United States, Spain, Russia, United Kingdom, Italy, France, Germany, Brazil, Turkey and Iran. High infection rates mean that these countries may have longer travel restriction periods imposed by both their own countries and inbound destinations, as well as airlines and other transport providers. While China had one of the highest rates of infection early on, it is now in the recovery stage and regional destinations may be able to tap into this market when travel is safe again (Figure 7). On the other hand, the United States continues to struggle, facing challenge from the pandemic and subsequent economic crisis. Destinations that are reliant on the United States market, like the Caribbean, may need to consider market diversification in the short-term (Figure 8). 
Figure 7. Chinese Outbound Tourism Flows 2018 (\%)

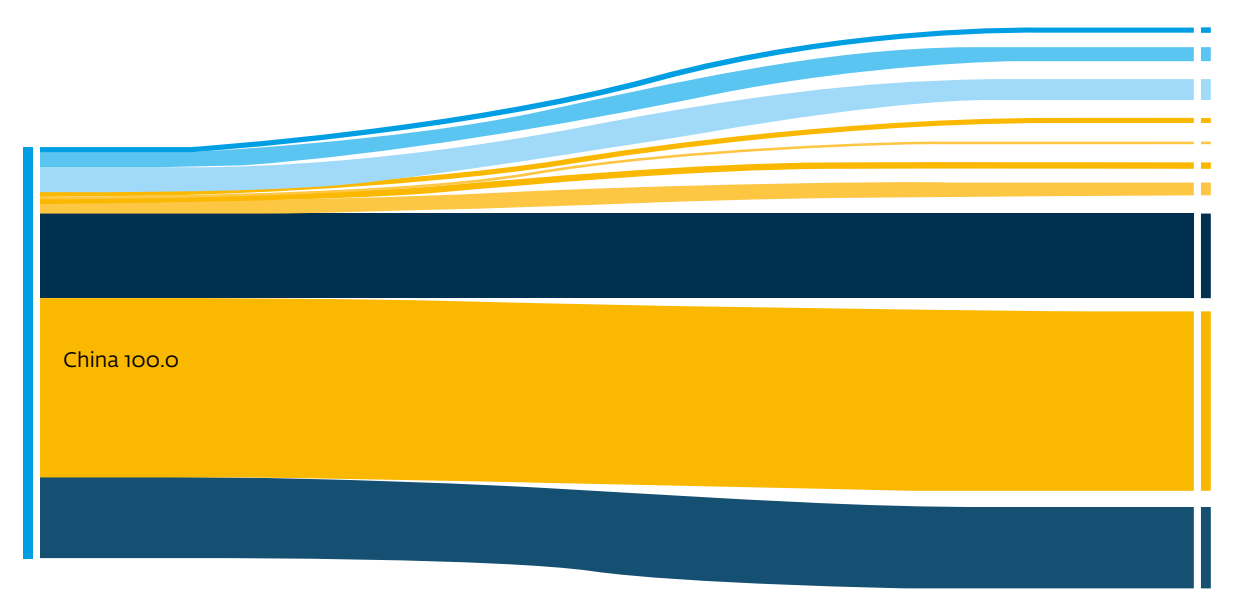

Sub-Saharan Africa 0.5

Middle East \& North Africa 4.0

North America 5.8

Latin America 0.4

Caribbean 0.

South Asia 1.5

Australia, New Zealand \& Pacific 3.4

East Asia 20.4

South East Asia 44.2

Europe \& Central Asia 19.7

"Excluding Hong Kong, Macao and Taiwan.

Figure 8. United States Outbound Tourism Flows 2018 (\%)

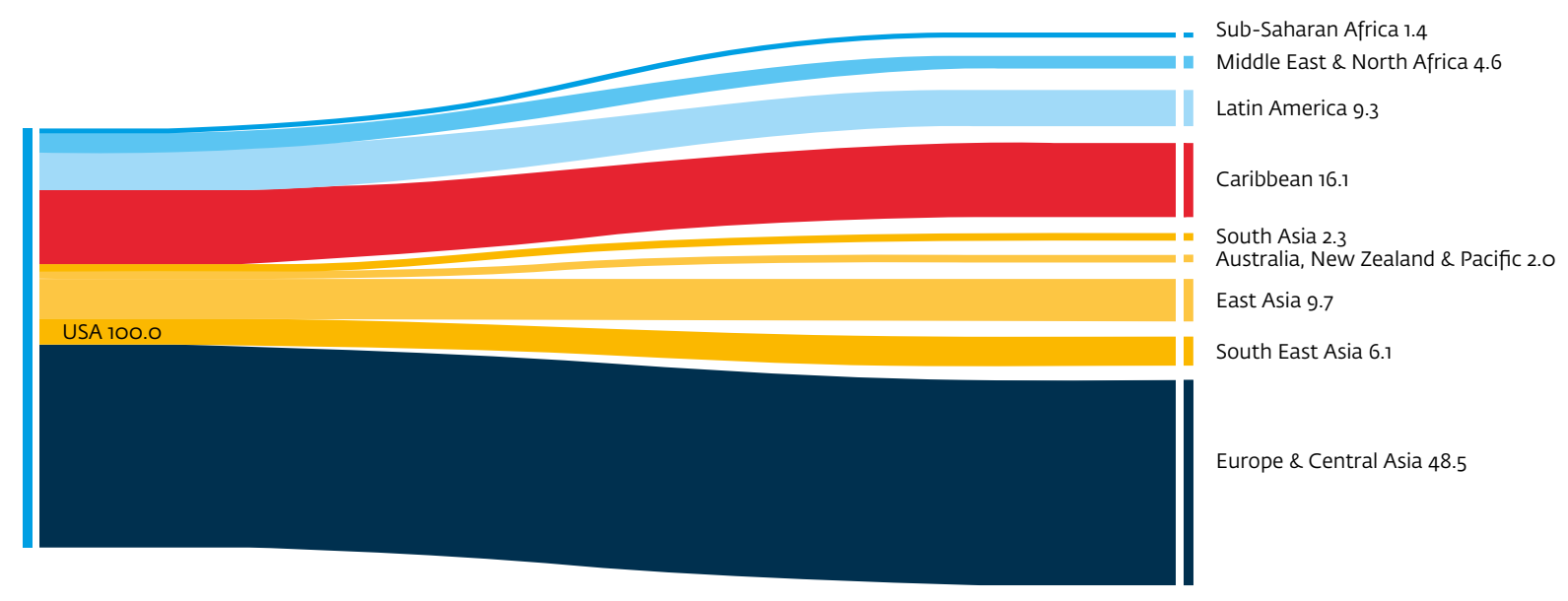

*Excluding Mexico and Canada.

Additional demand-side resilience assessments could include, for example:

- The size and value of the domestic tourism market as domestic tourists are regarded as likely to travel sooner than international visitors. Countries with a higher value domestic tourism market are likely to recover their tourism sectors faster.

- The size of the intra-regional markets may indicate the potential for regional recovery between closely-related safe-zones or regional 'travel bubbles' (e.g. 'Tasman bubble' between Australia and New Zealand).

- The number of COVID-19 cases in the country and the number in neighboring countries will impact the length of lockdowns and travel restrictions and the ability to get domestic and intra-regional travel restarted.

Although all the resilience data included here is limited to country-level, it should be noted that there will be large differences within countries dependent on both supply and demand factors. Any use of the above data for decision making should therefore be supported by additional destination-specific data points. The geospatial aspects of tourism resilience risk are important as they are likely to heavily impact vulnerable populations such as women and indigenous communities who tend to have fewer financial resources to withstand crisis. 


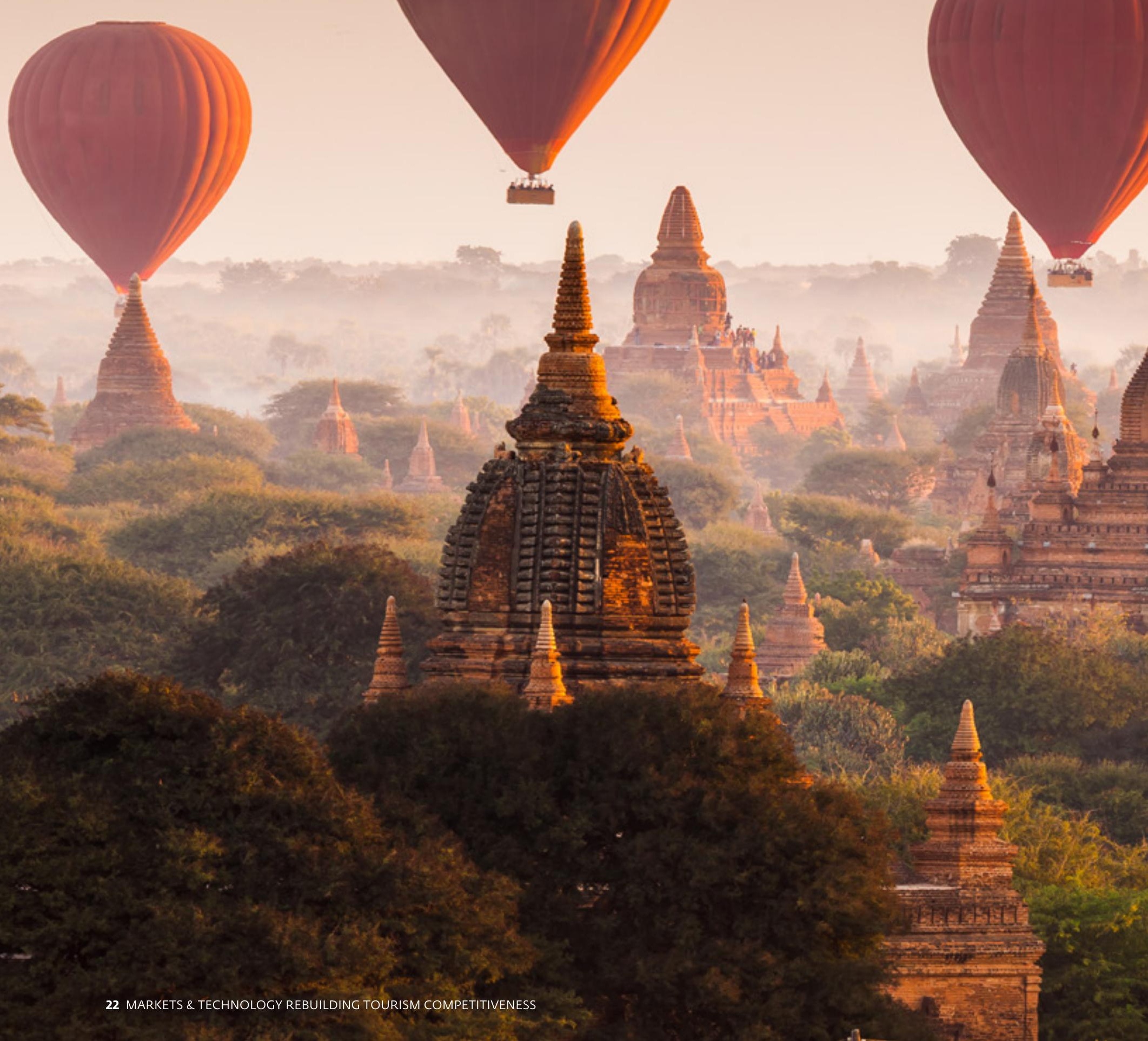




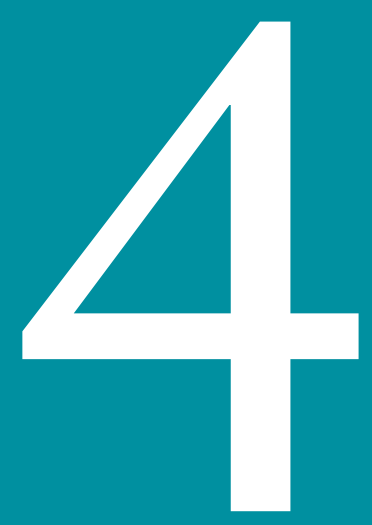

\section{Policy Responses}

Globally, tourism policy makers are responding in different ways. However, most of them agree on the need for two distinct phases of intervention - immediate response and recovery. The first relates to interventions (including policy) that respond to the immediate crisis. This implies the abrupt removal of almost all forms of tourism demand for an unspecified time and the corresponding shock to the industry. The second phase refers to the preliminary, followed by longer-term measures, to help the sector recover once signs of imminent recovery are identified. Policy interventions in the first phase focus on survival and support the private sector to maintain workforce. In the second phase, they focus on sector-wide reinvention, recovery, and building resilience. 
Policy interventions in more advanced economies are being rolled out to support the tourism sector at speed and scale. In developing economies, interventions are likely to follow a similar pattern, but with fewer resources and lesser capacity to implement them. Consequently, the sector's most effective responses are likely to emerge from multiple actors - government, other stakeholders, and private sector working together.

Policy responses include measures to support travel and tourism as a whole, as well as those targeted at specific subsectors. Measures include direct financial support to alleviate debt obligations, cash grants and subsidies, employment and training support, easing of regulatory burdens and waiving of fees and charges. In addition to economy-wide and sectorwide support, some policy interventions have been designed to support specific sub-sectors including hospitality, food services, hotels and transport. Several specific interventions have been targeted at the aviation sector. For further

Figure 9. Number of Measures by Income-Level

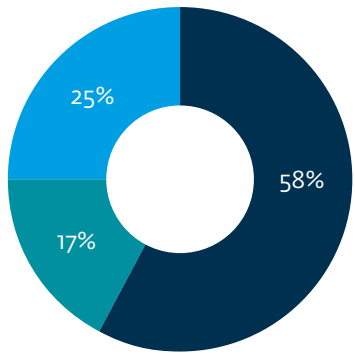

High income

Upper middle income

Lower middle income

Figure 11. Number of Measures by Country information on policy responses targeted to airline firms, please refer to: 'Support to systematically large firms in hardhit sectors: The case of airlines state-support programs amid COVID-19'. ${ }^{42}$ FCI's Markets \& Technology Global Unit had identified 205 individual policy responses in the tourism sector as of June $2020 .{ }^{43}$

High-income countries have deployed most of the identified interventions. As of June 2020, high income countries had deployed 58 percent of the identified interventions, with the balance composed by lower-middle income (17 percent) and upper-middle income (25 percent) countries (Figure 9). Countries in Europe and Central Asia have deployed the largest share (36 percent) of the identified interventions, followed by East Asia and the Pacific (22 percent) and Latin America and the Caribbean (13 percent) (Figure 10). Among individual countries, the United States has, however, deployed the largest number of identified interventions, followed by Australia (Figure 11).

\section{Figure 10. Number of Measures by Region}

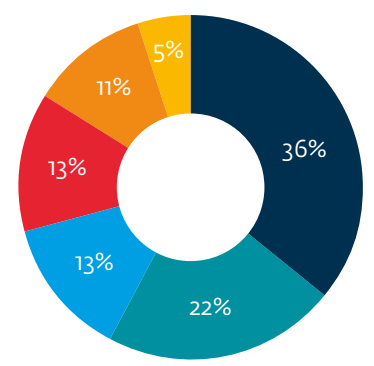

Europe \& Central Asia

Middle East \& North Africa

East Asia \& Pacific

- North America

Latin America \& Caribbean

Sub-Saharan Africa

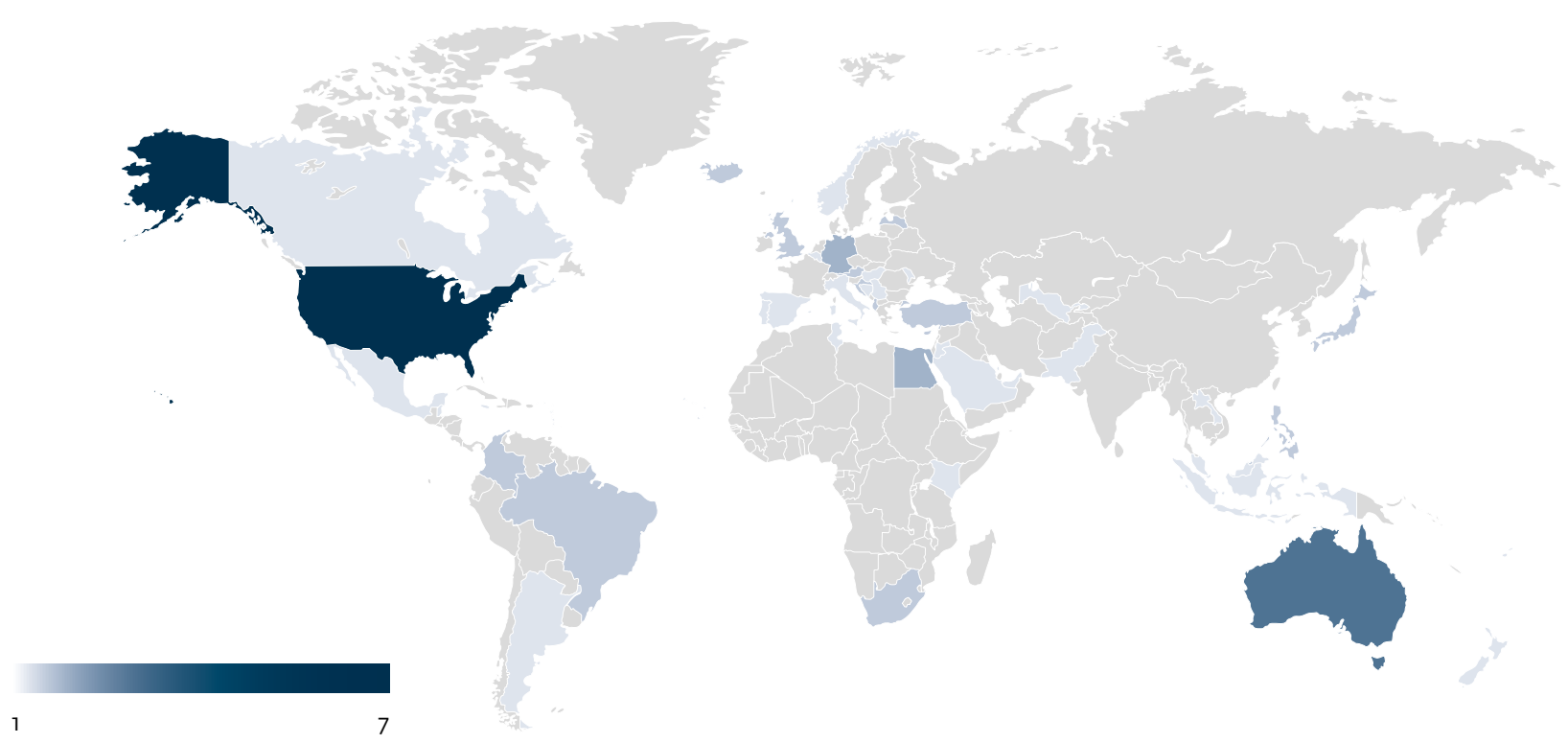


Figure 12. Number of Measures by Sub-Sector

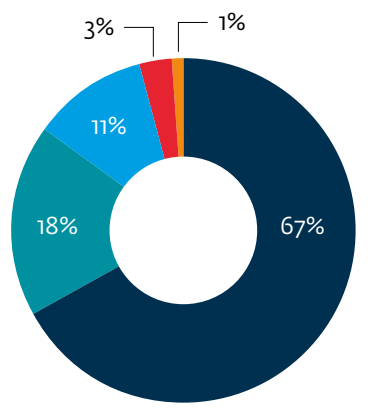

Tourism-wide

Aviation

Food services and hotels
Tourism-wide interventions are more common than those targeting sub-sectors and debt financing is the most popular instrument of measures tracked. Tourism-wide interventions comprise two-thirds of the identified interventions, followed by aviation-specific interventions (18 percent) and food service and hotel interventions (11 percent) (Figure 12). Debt finance is the most frequent type of intervention, followed by tax-related measures, and investment/capital-related measures (Figure 13). High-income countries appear to be relatively more likely to deploy debt finance measures and less likely to deploy tax-related measures (Figure 14). Measures in lower-middle-income countries have focused predominantly on debt finance and tax-related interventions, while those in upper-middle income countries have been relatively balanced across different types of interventions.

Figure 13. Number of Measures by Type

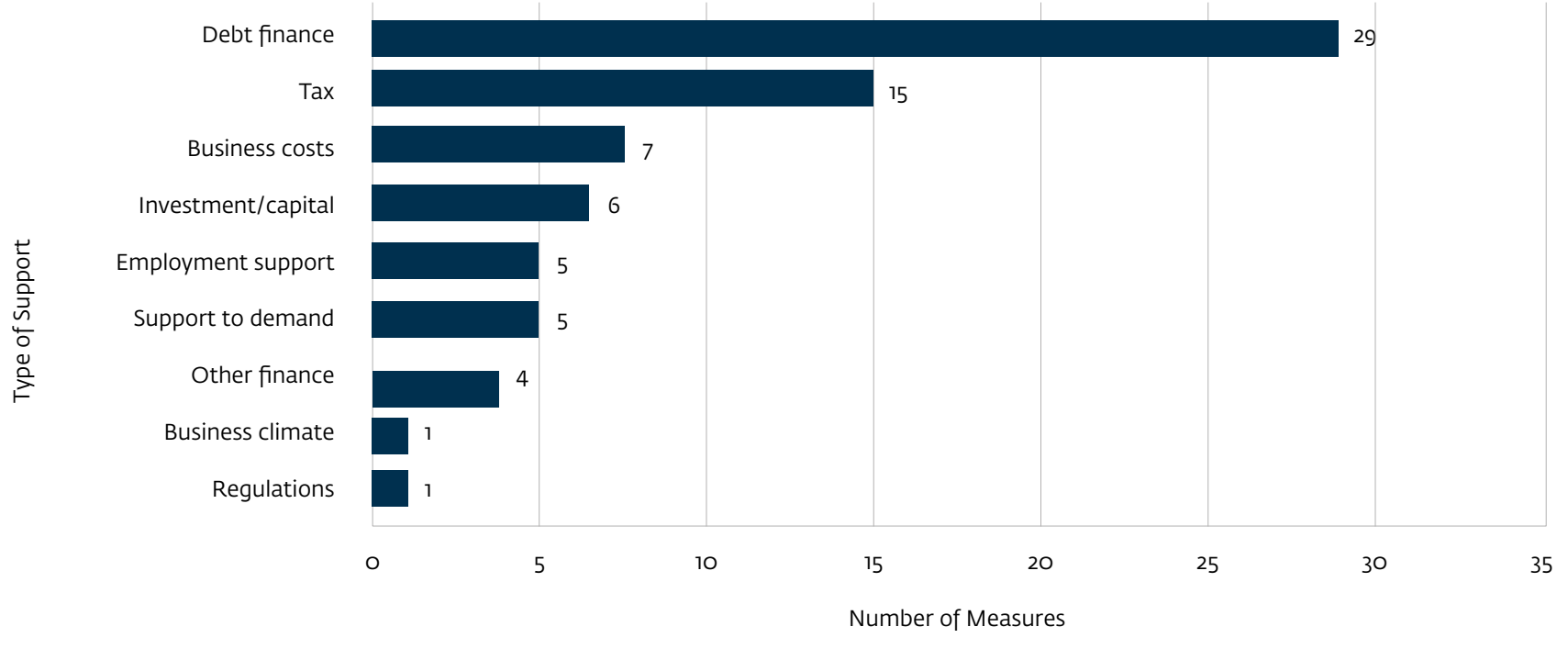

Figure 14. Type of Measures by Income-Level

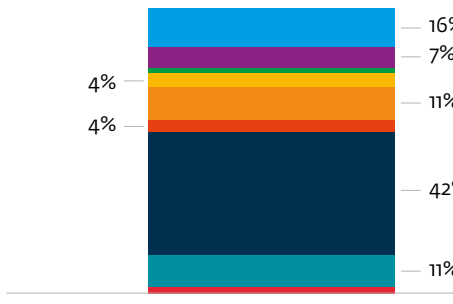

High Income

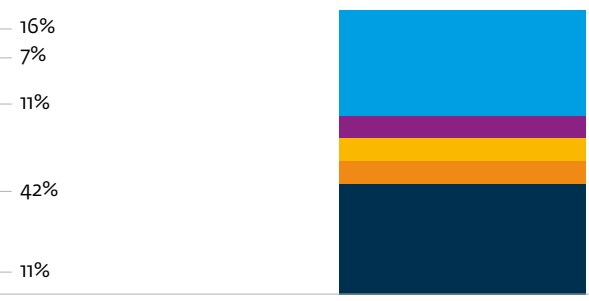

Lower Middle Income

Employment support

Investment/capital

\section{$38 \%$ \\ $-8 \%$ \\ $38 \%$}

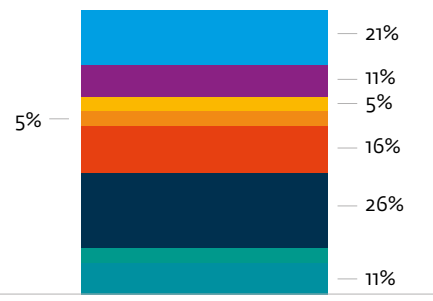

Upper Middle Income

Support to demand

Tax 
Some further examples of policy responses are shown in the table below.

Table 2. Examples of Support Measures and Policy Responses to COVID-19

\begin{tabular}{|c|c|c|c|c|c|c|c|c|c|c|}
\hline & Croatia & $\begin{array}{l}\text { South } \\
\text { Africa }\end{array}$ & Peru & Canada & Singapore & Indonesia & Fiji & Rwanda & Kazakhstan & Sri Lanka \\
\hline Cash grants/subsidies & $\checkmark$ & $\checkmark$ & & $\checkmark$ & $\checkmark$ & & & & $\checkmark$ & $\checkmark$ \\
\hline Tax rebates/relief & $\checkmark$ & $\checkmark$ & $\checkmark$ & & & $\checkmark$ & $\checkmark$ & $\checkmark$ & $\checkmark$ & $\checkmark$ \\
\hline $\begin{array}{l}\text { Loan repayment } \\
\text { support/credit support }\end{array}$ & $\checkmark$ & $\checkmark$ & $\checkmark$ & $\checkmark$ & $\checkmark$ & $\checkmark$ & $\checkmark$ & $\checkmark$ & $\checkmark$ & \\
\hline Training incentivization & & $\checkmark$ & & & $\checkmark$ & & & & & \\
\hline Rules alleviation & & $\checkmark$ & $\checkmark$ & & $\checkmark$ & $\checkmark$ & & & & $\checkmark$ \\
\hline Fees/bills waivers & & & $\checkmark$ & $\checkmark$ & & & & & & \\
\hline
\end{tabular}

Source: IMF COVID-19 Policy Tracker.

\section{The World Bank Group and Past Crises}

The COVID-19 crisis - in terms of scale, scope, and trajectory - has impacted the tourism sector in a way none of the earlier crises have affected the sector. In the past, despite disasters (SARS, Ebola, the 2008 GFC, H1N1), policy makers were able to plough through the crisis period and plan for recovery based on a likely end date.

In this case, the uncertain cycle and global nature of the pandemic puts the industry in a unique situation especially because an end date is harder to predict. Further, the pervasiveness of the virus leaves few options for travelers and operators. The 'immediate response' period before 'recovery' is the immediate concern. This means that policy responses must be designed to deal with the immediate survival of the industry in 2020. Support should be conditional to maintaining workers, and if support is provided to large firms, it should be conditional to paying vendors and avoiding massive layoffs. The same rules should apply to those that are considered strategic firms because of their input-output linkages.

Also, policy responses must be designed to support recovery and growth once travel bans are lifted and the market has the ability and desire to travel again. The World Bank Group (WBG) has supported client countries through diverse crises. Key lessons include:

- Emphasizing quality and maintaining focus. The speed and quality of bank response are crucial for positive outcomes during and after crises.
- Being selective and focusing on additionality. ${ }^{44}$ Support is stronger with selective coverage and focus on the World Bank's comparative strengths (for example, fiscal and public expenditure policies).

- Considering the poverty angle, inclusion and distributional impact. It is vital to attend to poverty dimensions from the onset of a crisis, and not only in its later stages. Customizing policy advice to the country context is as important as ensuring its technical quality.

- Monitoring impact. Support during crises is more successful when nested in a results framework (explicit or implicit) that incorporates post-crisis recovery.

- Using agile financing modalities and organizational arrangements. Programmatic Development Policy Loans can be fast-tracked to address crisis needs more easily than Investment Project Financing. Also, additional instruments may be needed for initial liquidity support as part of multipartner packages. Internal organizational arrangements can make a big difference as they affect the degree of preparedness, cross-sectoral coordination, timeliness of response, and appropriateness of instruments - all of which help get results.

- Coordinating with partners. Collaboration across the WBG and with outside partners, including industry, strengthens program effectiveness and is essential to exploit synergies, avoid overlaps, and maximize impact. 


\section{Thinking Forward in the Context of Uncertainty}

Historically, demand is known to rebound after a crisis, although the recovery time and the recovery profile varies. Analysis by McKinsey ${ }^{45}$ shows that after SARS (2003) and MERS (2015), it took between three and five months to recover to pre-crisis levels of demand. Air passenger volume had a steeper and longer-term drop post-9/11, and the GFC recovered to 90 percent of original demand levels within 10 months. After the GFC, airlines moved to lower prices to spur demand and accelerate recovery. However, the financial crisis had a longer and larger impact on hotels, taking them years to recover their occupancy rate and revenue. Evidence from previous crises shows that there are lags in the different stages of recovery - demand (passengers/visitors) first, followed by revenues, profitability and finally investment. While these indicators provide a useful backdrop, little is known at this time to predict the recovery profile of COVID-19.

Currently, the information available is insufficient to make reliable predictions concerning the geographical and temporal distribution and intensity (in terms of morbidity and mortality) of the global pandemic. In the absence of such predictions, it is difficult to gauge the economic and psychosocial impacts that the virus may have on the travel and tourism industry in the aftermath of the pandemic. If the pandemic is not contained, international travel and tourism may remain stunted for a longer time. This may apply even if the geographic distribution of the pandemic remains uneven. Countries that are relatively unaffected are likely to retain restrictions on travel from countries that are more affected.

As the crisis continues to unfold, destinations and businesses will face ongoing challenges as well as opportunities. Impacts, trends, and sector needs are changing on a daily basis, making it difficult to predict the new and uncertain future of travel and tourism. However, assessing and analyzing key trends to gauge the shifting ecosystem through pulse surveys - with both supply and demand-side actors - will help inform evidence-based decisions (see section below on Phase 2: Short-term Recovery for specific guidance). Once there are signs of recovery, the Bank can leverage this information to inform clients on how to best guide recovery and how to build a better industry in the near future. Moreover, the global recovery period provides a unique opportunity to move the sector forward by addressing persistent challenges for a stronger and more resilient sector.

At a high level, the following are key points to watch and monitor through pulse surveys with suppliers, travelers, and research.
1. Tourism recovery will be uneven. The recovery process will be at a varied pace and scale in regions, countries, and destinations. Destinations that understand their markets in terms of investments, services, and marketing campaigns required to attract customers, will be more successful. This may mean investing in regulation and policy to open air routes, increasing visa openness, supporting $\mathrm{P} 2 \mathrm{P}$ accommodation, increasing health and hygiene in hotels, and others.

2. Demand for particular tourism products/segments may be reshaped leading to new forms. While it is unclear which products and segments will be impacted, it is likely that the market will seek different types of experiences. Initial surveys with travel consumers indicate that future demand for cruise will be low. Similarly, with increased tolerance for virtual meetings and discussions, demand for products related to business travel may be reshaped. Governments should focus on trends in their key market segments and should be ready to accept that some business models may not be viable in the short-term such as nightclubs, mass religious gatherings, sporting and music events, shopping outlets or entertainment venues which rely on high traffic volumes. This will help them determine what products and services they may need during the recovery period and target investments on high-priority markets. Governments could also leverage technology and online platforms for expanded benefits of the industry.

3. Consolidation of major operators in varied segments is likely, starting with airlines and hotels. In a scenario where global slowdown affects small and medium companies and less developed economies ${ }^{46}$ more acutely, much of the diversity and sheer inventory of service providers may diminish. The larger firms, such as national airlines, tour operators, cruise lines or globally branded hotel operators, are more likely to withstand stress or receive significant government support. Thus, in a recovery scenario, only a few players will be in a position to respond to the emerging post-COVID-19 traveler demand, thus absorbing their erstwhile competitors' share. It is possible that larger firms will invest in vertically integrated value chains. For example, a tour operator may need to invest in charter aircraft, hotels, transport services, and guides because these individual enterprises may not exist anymore. Further, these firms may take the opportunity to expand into new markets or diversify to capture more of the market share. This 'consolidation' effectively means more larger vertically integrated and diversified enterprises, and more ownership/control of these enterprises in advanced economies. For our client countries, this implies less economic value and opportunity within the tourism sector unless there is strategic intervention. In the short-term, destinations should continue to monitor the changing dynamics and identify strategic anchor businesses to build stronger relationships. 
4. More liquid and agile players who can withstand the severity of the downturn could have a significant impact on how countries emerge. For example, large OTAs can easily switch between models and move demand quickly between destinations. They will be assessing which countries are coping better with the crisis and the recovery. This means, countries and destinations that are more 'market ready' will be better placed to handle demand. Destinations are likely to be dependent on bigger players to drive demand - large hotel companies and airlines. Smaller businesses will struggle, and unaffiliated operators will be on their own. SMEs, destinations, and even some of the hotels will need support on better engaging with OTAs to build strong distribution channels.

5. Governments will be conflicted. The need to capture renewed tax revenues just as firms are struggling to reopen or bounce back will put local, municipal/ provincial, state and national governments in a difficult position. Creative solutions will be essential to enable the sector's ability to generate jobs. Firms - while looking for adequate public funds to support such efforts - will require a new generation of policies and programs. As the industry rebounds, deferred taxation and prolonged tax holidays will inspire confidence in the private sector.

6. Many businesses that were directly or indirectly connected to tourism will need assistance to survive. Prioritizing private sector financing solutions will enable these businesses to restructure. It will further ensure that only those firms best able to lead the recovery are supported so that supply can respond quickly when demand resumes.

7. As the effects of the pandemic continue, it will be increasingly difficult to support all firms. Support may need to be channeled to firms that have higher potential to: lead recovery through stimulating demand, tap into larger financial and organizational capital (which may be difficult to replace), and those with greater capacity to support other less resilient firms in the supply chain. Consequently, policies will eventually adjust to the type of firms to be supported, the amount of resources available and the administrative capacity of each country. Due to the collapse in demand across travel and tourism and attendant deterioration in asset quality, the crisis has resulted in a surge in firms seeking to restructure their debt profiles. In order to ameliorate the impact of the shock on otherwise solvent firms, create orderly exits for those that continue to survive, and lessen the deflation of asset values, countries may need to strengthen insolvency and resolution frameworks. These include legal frameworks for corporate and consumer debt restructuring and outof-court conciliatory measures. In particular, it will be important for governments to introduce temporary and time-bound measures to restructure debt and prevent premature insolvency while not hindering processes to liquidate failed firms.

8. Governments will need to be aware of the trade-offs they face in determining policy responses. For example, while the timing of reopening borders will have a large impact on the survival of the sector, it can also damage destination credibility if done too early and infections increase. Further, many developing countries have limited fiscal space to support the sector beyond a few months, and governments may need to prioritize support across the whole economy. Keeping people employed in sectors that may take longer to bounce back could risk restricting the ability of the market to channel resources to other sectors which might recover more quickly.

\section{Advice for World Bank Clients}

The World Bank's response to client need is especially critical at this time. Countries including Sri Lanka, Zimbabwe, Indonesia, Tunisia, Ethiopia, Albania, Egypt, and the Caribbean Islands have already sought advice on recovering their tourism sectors. The M\&T Global Tourism Team, while monitoring government responses, provides a menu of options (below) based on the model of immediate response followed by recovery. An initial set of options was provided in a World Bank note and blog. ${ }^{47}$ Appendix 3 contains menus of response options by tourism subsector as well as options for policy makers. The following are organized by immediate, medium-term and long-term response. They cover, broadly three main areas shown in the figure below with further country examples in Appendix 3.

\section{Figure 15. Response Framework}

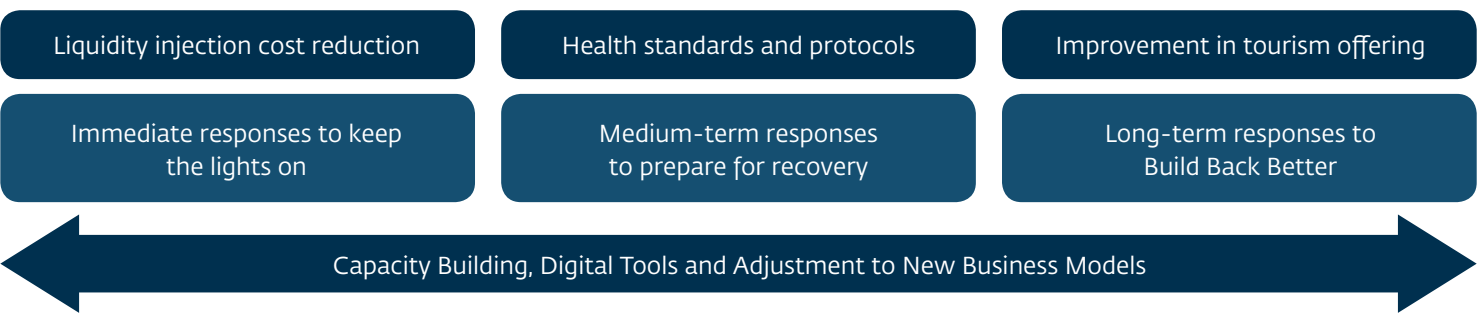




\section{Phase 1: Immediate Response (during the crisis and early recovery)}

Effective policy responses that can be utilized during the crisis period have been identified from destinations around the world. The initiatives aim to help the industry avoid insolvency and support tourism stakeholders so that they are able to launch recovery when the time is right. Though not exhaustive, below is an initial list:

- Accepting and embracing travel bans. In countries where the spread of the virus is most virulent, tourism policy has embraced public health directives and has stopped marketing of any kind, urging everyone to stay at home. The sooner the outbreak is under control, the faster the industry can start recovering. Estonia is an example. ${ }^{48}$

- Communicating effectively. Many tourism boards and Destination Management Organizations (DMOs) are being proactive and keeping the industry and public informed about the latest developments affecting the destination. One specific approach is to create a National Response, Communication, and Recovery Task Force including both public and private sector members. This positions the destination as responsible, inspiring trust and confidence among stakeholders.

- Deterring and monitoring all arrivals. All countries have some level of international travel restrictions in place. For example, Saudi Arabia and Australia have restricted entry to only citizens and residents. This is only increasing with time. Other countries have instituted a mandatory 14-day quarantine requirement for any arrivals (Hong Kong). ${ }^{49}$

- Waiving of fees by national carriers to retain revenues. National carriers, along with most other commercial airlines, took measures to inspire confidence among consumers by waiving change and/or cancellation fees for future bookings. Fiji Airways, for example, is selling bulk tickets for forward bookings to premier and corporate clients and waiving all change fees to generate income in the short-term.

- Property tax rebates or payment deferrals. These are utilized for hotels and other tourism businesses, including for tenants in government properties, parks or facilities. The United Kingdom government has announced a 100 percent business rates holiday for the next 12 months to cover all retail, hospitality, and leisure businesses. ${ }^{50}$

- Government grants. A policy of small grants for vulnerable businesses is being deployed to support enterprises with short-term liquidity concerns. The United Kingdom is offering further assistance of up to $£ 25,000$ for businesses in hospitality, leisure, and retail. ${ }^{51}$ The Business Employee Support and Transfer (BEST) program, launched by the government of Jamaica, will provide temporary cash transfers to businesses operating in the hotels, tours, and attractions of the tourism sector. ${ }^{52}$

- Government tax relief. Policies are in place to suspend or reduce income tax payments, business rates, value added tax (VAT) and other fees applicable to business, including pay-as-you-earn (PAYE) deferral or exemption to provide relief to staff on reduced incomes. New Zealand $^{53}$ announced large-scale tax relief packages, and Myanmar ${ }^{54}$ has waived two percent advanced income tax on exports.

- Wage subsidies and income support to workers. In New Zealand, businesses hard hit by the virus - experiencing more than 30 percent decline in revenue compared with last year - are eligible to receive wage subsidies to keep paying staff. ${ }^{55}$ Direct cash payments can be used for workers who are most at risk including those operating in the gig economy.

- Support for industry to address contamination and protect the health of workers. Governments are providing grants or subsidies to businesses to help contain the spread of the virus and to protect visitors and employees. For example, public minibuses in Kenya are carrying hand sanitizers. Singapore is supporting third-party costs of professional cleaning services incurred by Singaporelicensed hotels that have provided accommodation to suspected and confirmed COVID-19 cases. $^{56}$

- Subsidized training for tourism industry workers to forestall layoffs. As a containment step, all staff should undergo health, hygiene, and emergency response training. During the extended crisis period, workers in Singapore are enrolling in government-funded training programs and are being paid a portion of their salary $(90$ percent of wages for hourly workers). Effectively, this is a subsidy for employers to keep workers on their payrolls instead of laying them off, with the added incentive of upskilling them and boosting their productivity when their services are needed in the post-crisis period.

- Repurposing tourism assets for crisis operations. Several countries have already signed agreements with tourism facilities - hotels and conference centers - to repurpose the facility for medical housing or quarantine. ${ }^{57}$ In Jamaica, Sandals Hotel has made the 38-room Sandals Carlyle available for patients who are recovering and need to be monitored. ${ }^{58}$

Apart from governments, many other actors have stepped in to respond during this crisis period, especially the banking sector. Local banks are under pressure from both government and industry to extend lines of credit and working capital, and to defer or reduce debt servicing obligations. In developing countries where resources are more limited, the demand for a coordinated approach is going to be even greater. 


\section{Phase 2: Short-term Recovery}

Once the crisis subsides or when the end point is clear, there will be an immediate need for policy responses to support the recovery period. As noted earlier, recovery may not necessarily mean a full return to the pre-pandemic scenario but an economic recovery of the sector. This may involve new business models. Based on experience, policy approaches for implementation immediately after the crisis include:

- Developing a periodic survey and assessing the need of the tourism private sector. In times of crisis, information and data are critical. A high-frequency monitoring phone/online survey ('barometer' or pulse survey) in collaboration with concerned industry associations and/ or key informants can help identify emerging issues and monitor recovery. These pulse surveys can also provide insight into the needs of SMEs during the response and recovery phases for evidence-based decision making and real-time sector analysis. Destinations should also monitor changes in traveler sentiment to understand which market segments will be the first to travel again and what investments are required to attract more risk-adverse markets. For example, these may include improved health and hygiene at hotels and airports, permanent health screening at airports, improved local health care, and others.

- Utilizing the new IFC Fast Track COVID-19 Facility - the first phase of its recovery response, worth up to $\$ 8$ billion in immediate support - to assist private sector companies to cope with the impact of the global pandemic. The IFC Facility will deliver fast and flexible solutions to clients across sectors and countries dealing with the spread of COVID-19. As part of the facility, there is a $\$ 2$ billion Real Sector Crisis Response Envelope and a $\$ 6$ billion Finance Institutions Response Envelope. The package focuses on providing financing for existing IFC investment clients that are in good standing. Within the tourism sector, this will focus on clients mainly in the accommodation sector.

- Incentivizing business expansion and entrepreneurship. Waivers for permit/license fees (both new issuance and renewals) for hotels, travel agents, and tour guides. These can also be broadened for transportation services such as taxis and small buses. Permits and licenses should still be issued to ensure quality and safety standards and measure sector recovery. Incentives for SMEs and innovative ideas that fit the destination's new strategic identity should be considered.

- Identifying target markets and ensuring openness. Some markets will be more resilient and come back sooner to the destination (domestic, diaspora, repeat visitors, younger demographics). Ensuring that products, pricing, and access (visas, direct flights) are appealing will be important. Declaring special holidays and offering tax deduction programs for domestic travel can help boost immediate domestic tourism.

- $\quad$ Strategizing for recovery. When planning and positioning the destination for a 'rebirth,' analyzing and adapting market position, product alignment, and regulatory and zoning frameworks will help achieve the vision. Using this opportunity to reposition and renew products and services will help the destination become more competitive. Online services in travel and tourism should be offered to maximize digital platforms and technology.

- Relaunching destination through 'back in business' augmented promotion to key source markets. Promotion and marketing budgets should be back to pre-crisis levels and augmented funding can support international outreach and 'open for business' promotion activities; leverage regional promotion and coordination; and create a communications, branding, and market positioning strategy, eventually delivering a series of business-to-business events and communication messages, together with targeted marketing campaigns to select market segments.

- Assisting informal businesses to get registered where possible. While governments should not force informal businesses to comply with complex legal requirements, it is likely that many of the benefits/subsidies that are or will become available can only be accessed by registered entities. Governments may ask informal businesses to simply register in order to access benefits and for better information, which can help later design policies towards the informal sector. The vast majority of informal businesses are highly dependent on social networks and community-based financing and do not have access to the traditional financial sector. These may be best targeted through leveraging social protection, microfinance and fintech solutions.

- Improving access to finance for registered tourism SMEs. Access to finance should be assessed, prioritized, and facilitated on favorable terms for key tourism SMEs through guarantees, subsidized loans, extended credit lines, non-collateral financing, and a grace period for new loans. Support for SME finance can be complemented with support to improve their capabilities, including upgrading their offerings and connecting to markets through digital platforms.

- Enhancing access and establishing additional global gateways. This could mean waiving or reducing landing fees and passenger airport taxes and expanding access from individual countries with increased flights as operational supply reopens. 
- Understand the trade-offs of extending discount offerings. The desire to reestablish arrival volumes by discounting on flight tickets, hotel stays, vacation packages, and others, can be counterproductive. Past experiences show that once travelers are aware of heavily discounted prices, it raises their expectations and they start viewing these prices as the 'new normal.'

- Mobilizing digital platforms. P2P and other online platforms may provide fast replacement for conventional products in the immediate aftermath of the crisis to address potential shortages due to bankruptcies and staff losses. A policy framework that allows these businesses to operate legally, pay taxes, and receive training in online sales should be considered. Digital technology may also be used by DMOs to improve safety, visitor management and crowding using real-time monitoring.

- Devoting efforts to training and upskilling. During the recovery period, reassure and retain staff at all levels for the long-term. Overcome the sector's reputation for instability and sudden job loss with a focus on stability and longer-term job opportunities in the sector. In St. Maarten, following Hurricane Irma, employees from heavily damaged hotels were channeled into government sponsored training while hotels were rebuilt. Time in training was paid for in the form of wages.

\section{Phase 3: Medium-term Recovery}

Once travel picks up and gains momentum, destinations need to consider instituting additional policy measures to be better prepared for future shocks while improving competitiveness and building resilience - Building Back Better. Below are some examples:

- Direct public investment and conservation for jobs and sustainability. The accelerated implementation of selected labor-intensive civil works or conservation projects can help upgrade or reposition the destinations, while creating jobs for low-skilled workers as it did for U.S. National Parks during the Great Depression. ${ }^{59}$ For example, this could include small infrastructure upgrades, reforestation/afforestation activities, river and water channels cleaning, trail building or maintenance, or coastal conservation activities.

- Build awareness of tourism crisis management and expanded training and certification programs for managers to be qualified in tourism crisis management and response.

- Establish a crisis escrow account for rapid communication response for the next crisis. Define structure, trigger processes and establish funding. This should be done along with capacity building for rapid response at the start of the next crisis and with strengthened coordination of public and private sector collaboration.
- Strengthen coordination of public and private sector collaboration. The ecosystem required to deliver goods and services to tourist markets requires a range of integrated activities across several government institutions to coordinate policies, planning, investments, and regulation. Destinations should review bottlenecks and overlapping activities, align resources with pressing needs, and streamline public sector organizational responsibilities for improved effectiveness.

- Define zoning policies to assure sustainable development, particularly in areas of natural and cultural heritage sites. Develop and enforce zoning guidelines in urban and rural areas to protect green areas and cultural heritage, and assure sustainable development going forward.

- Invest in renewal. Upgrade and renew assets, products, and services in the destination to be more competitive, including training service providers.

- Support sector sustainability through greening. Expand current programs and incentives for greening of the tourism sector and protect against increased single-use plastics and improper disinfectant usage. Destinations and businesses have an opportunity during this global tourism pause to reset their intentions and rebuild a tourism sector that is more sustainable, more valuable and better for local communities and the environment. This could include incentivizing use of renewable energy sources and green and climate smart technologies. ${ }^{60}$

- Diversify geographically. Strengthen efforts to diversify tourism geographically — from resorts to rural lowdensity destinations.

- Improve data collection and support background analytical work to identify future market demand and new product development to enable a fast recovery. Strengthening systems that adequately measure economic impact, employment, and fiscal revenue are important tools to build a stronger political economy around the tourism sector. Assess capacity in tourism data collection, dissemination, and market research for domestic and foreign segments to diversify markets and identify vulnerabilities.

- Tackle structural changes that can enable improved competitiveness. Destinations, working in conjunction with their national governments, can leverage crisis insights to shift from traditional products to those in higher demand in the reconfigured marketplace. Opportunities to foster contestability across different markets within the sector could be revisited.

While there will be opportunity to mobilize a wide range of policy options in the recovery phases, the immediate need is to focus on managing the present crisis. 


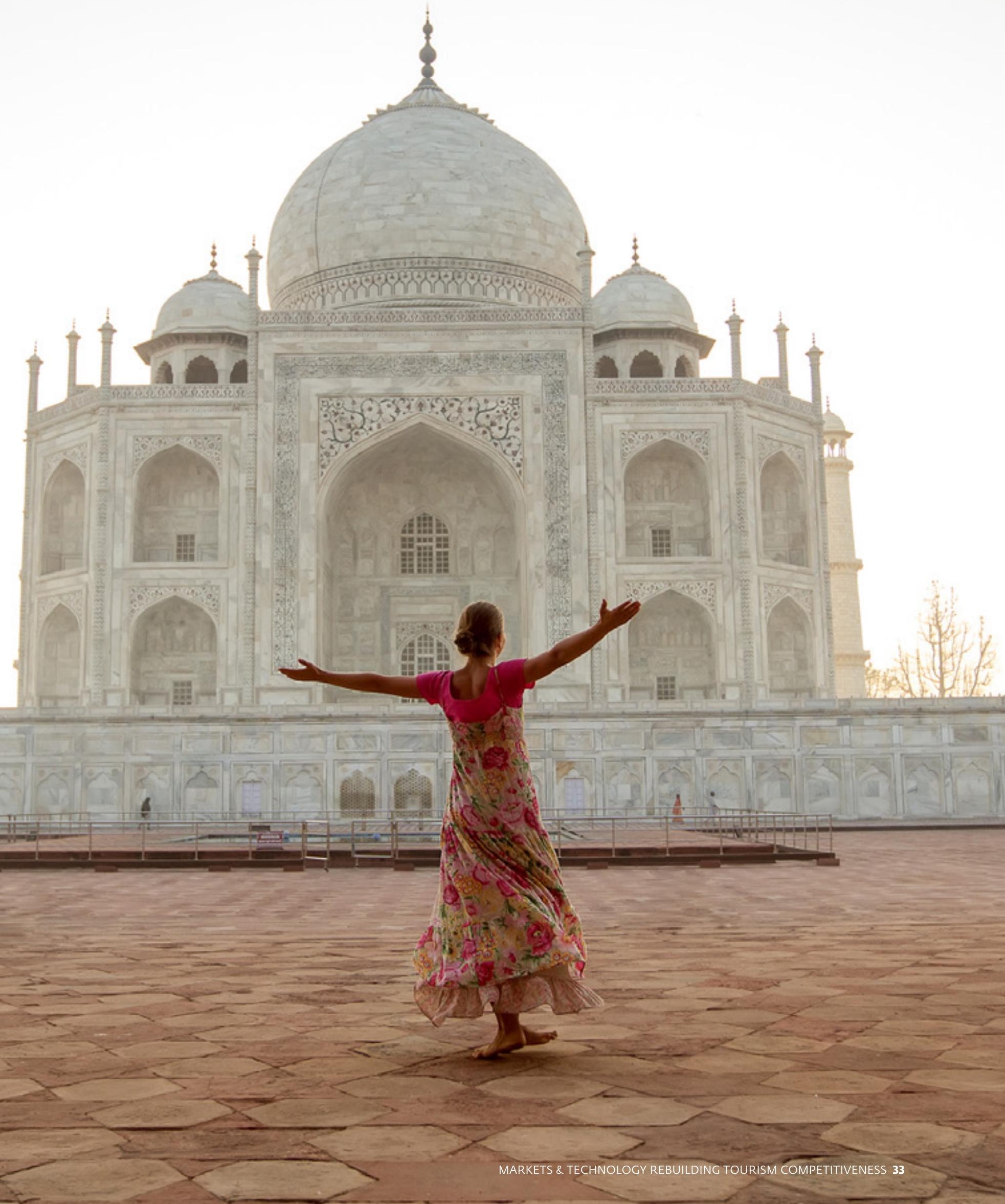




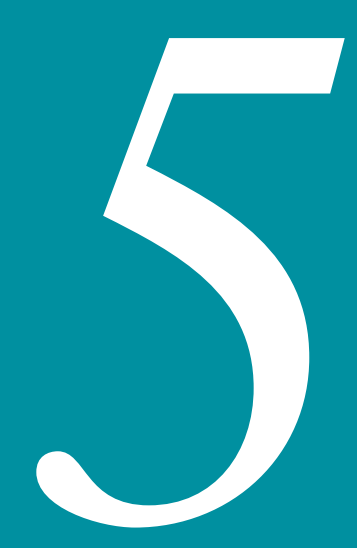

\section{Closing Considerations}

The COVID-19 global crisis is unprecedented. The uncertain lifecycle, geographical and temporal distribution, and intensity of the pandemic make it impossible at this time to predict the actual timing and path of recovery. However, one thing is certain: the global travel and tourism industry is already facing, and will continue to face, extraordinary challenges. The five biggest of these are: i) increasing focus on health and hygiene standards; ii) understanding how demand is changing (including the role of domestic and regional tourism); iii) interpreting changing business models due to consolidation and corporate restructuring; iv) mobilizing innovation and technology solutions impacting distribution and market access; and v) guiding public investments in destinations to position them for a more sustainable and resilient tourism industry post-COVID-19.

Recovery will require phased actions and creative policies enabling all stakeholders to adapt to a new business landscape. The public and private sectors along with destination communities will need to work together to create solutions. Historically, demand is known to rebound after a crisis, though the recovery time may vary. In this instance, the tourism sector can expect substantial change in supply and demand patterns emerging from this crisis. There will likely be a downturn in disposable income leading to less travel for some groups, and renewed travel for higher-end market segments. Corporations are likely to experience consolidation as SMEs face extended distress and even bankruptcy. The World Bank will, therefore, also need to be flexible in its responses. 
Amidst this change, the future also promises many opportunities for the sector to excel in its new form. The post-COVID-19 global business environment will offer unprecedented opportunity to address the sector's longstanding structural challenges, which have traditionally contributed to its underperformance. There will be scope to build back better with greater resilience and innovation at a time when new technologies can offer widespread benefits across the value chain. Supporting our clients to leverage these new opportunities strategically and efficiently is an unprecedented priority for the World Bank leadership.

\section{Appendix 1: Global Aviation Data}

Figure 16. Ratio of Year-on-Year Global Passenger Flight Arrivals by Country between Week of June 15, 2020 and 2019

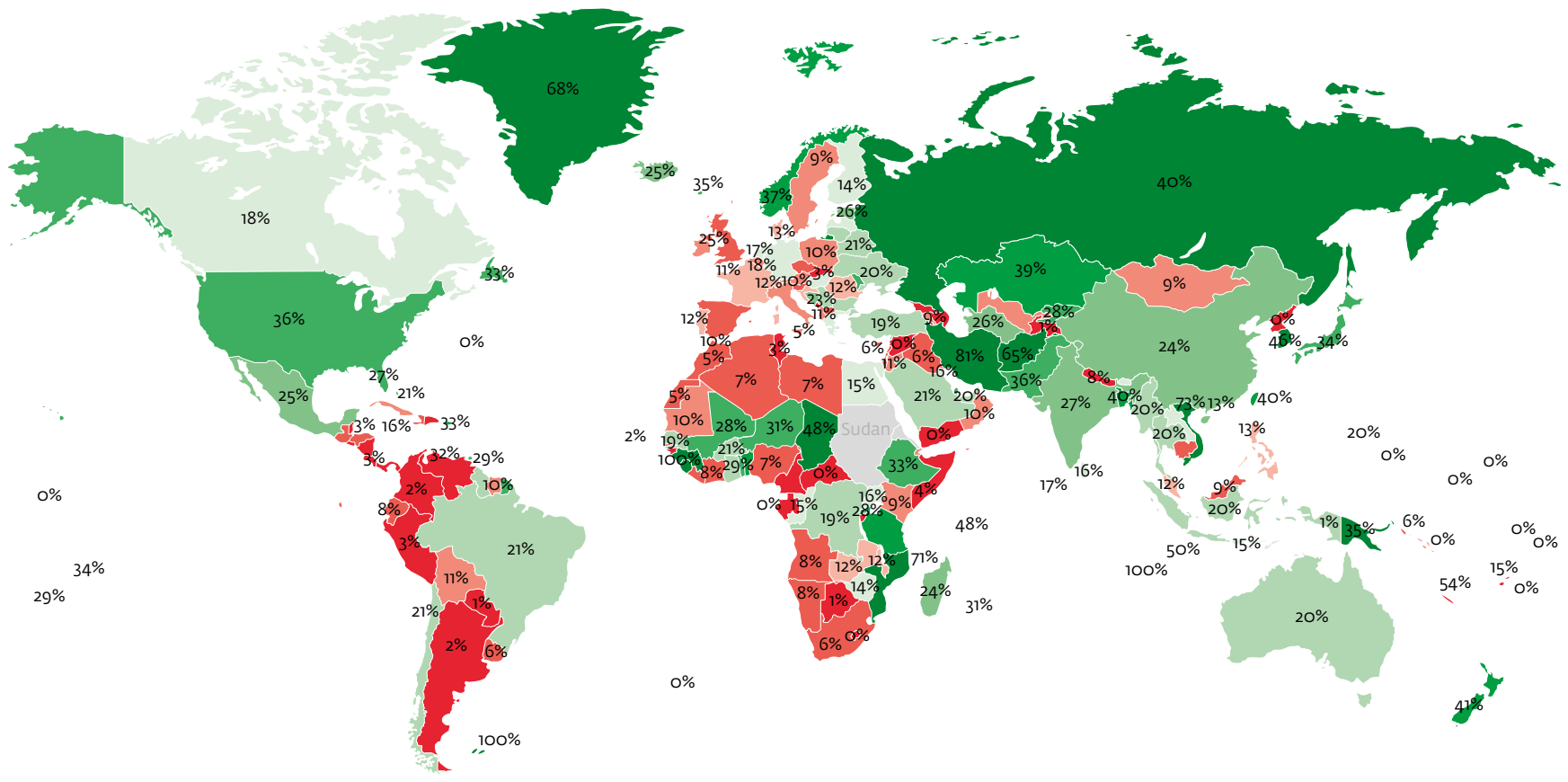

Percentile of Y-on-Y Change

०

$100 \%$

Source: ETIMT Analysis using FlightRadar24 Data.

Note: Colors have been scaled by percentile rather than raw percentage to highlight variations. 

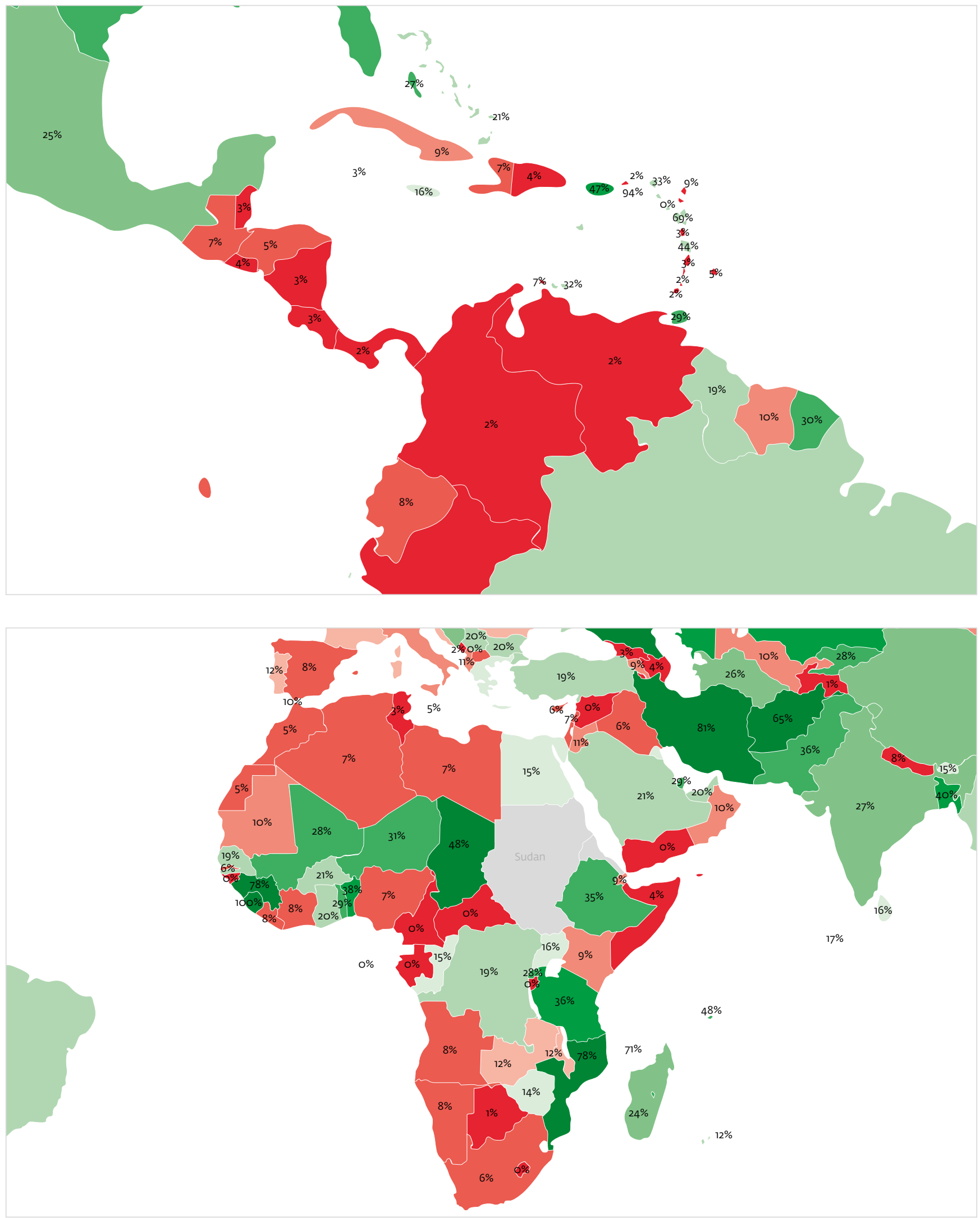

Percentile of Y-on-Y Change 

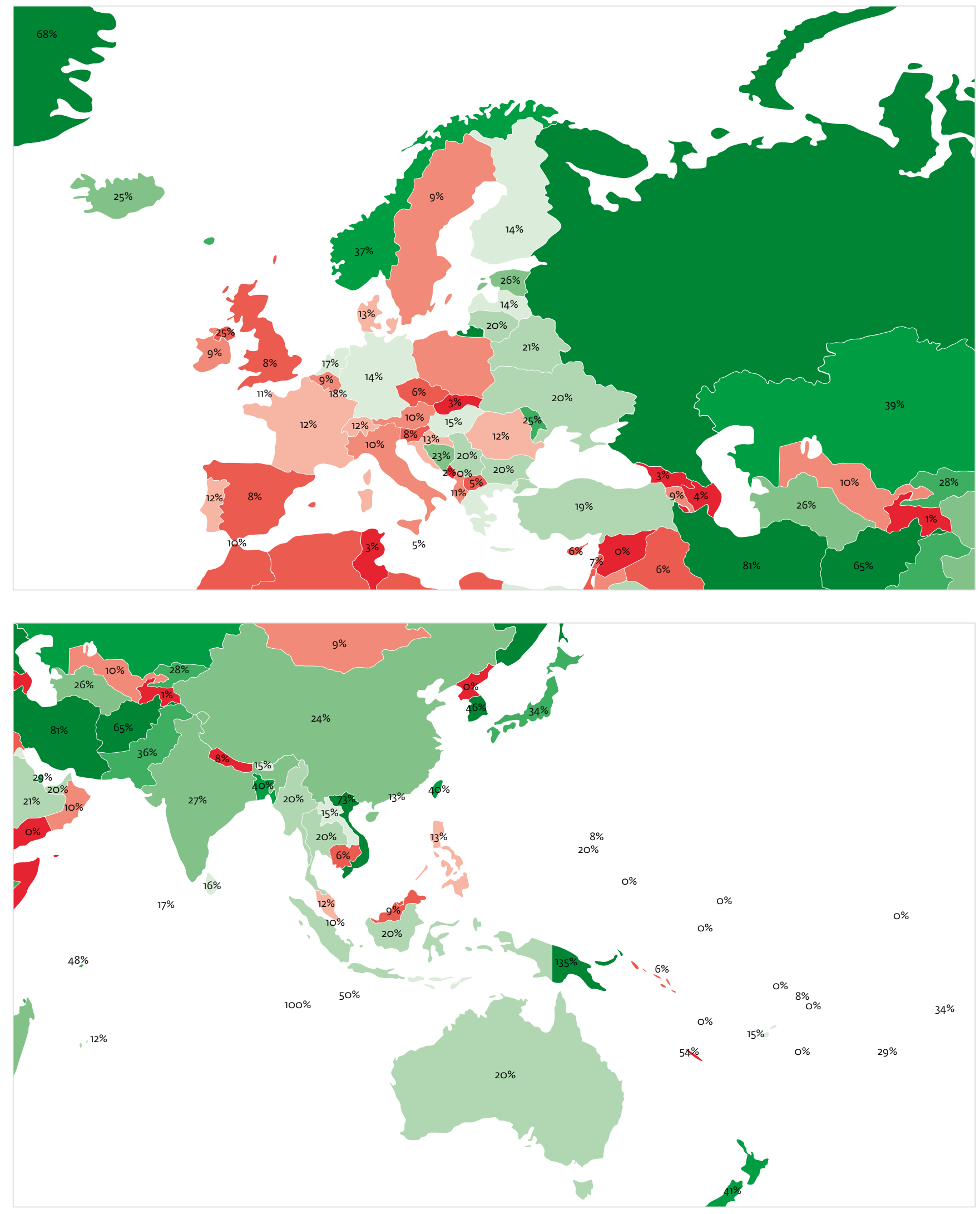

Percentile of $\mathrm{Y}$-on-Y Change 


\section{Appendix 2: Regional and Country Vulnerability Data of Tourism: Economic Dependence and Tourism Resilience Risk Score}

Figure 17. Total Contribution of Travel and Tourism to GDP, by number of countries with Severe, High, Medium or Low Dependency (WTTC, 2019)

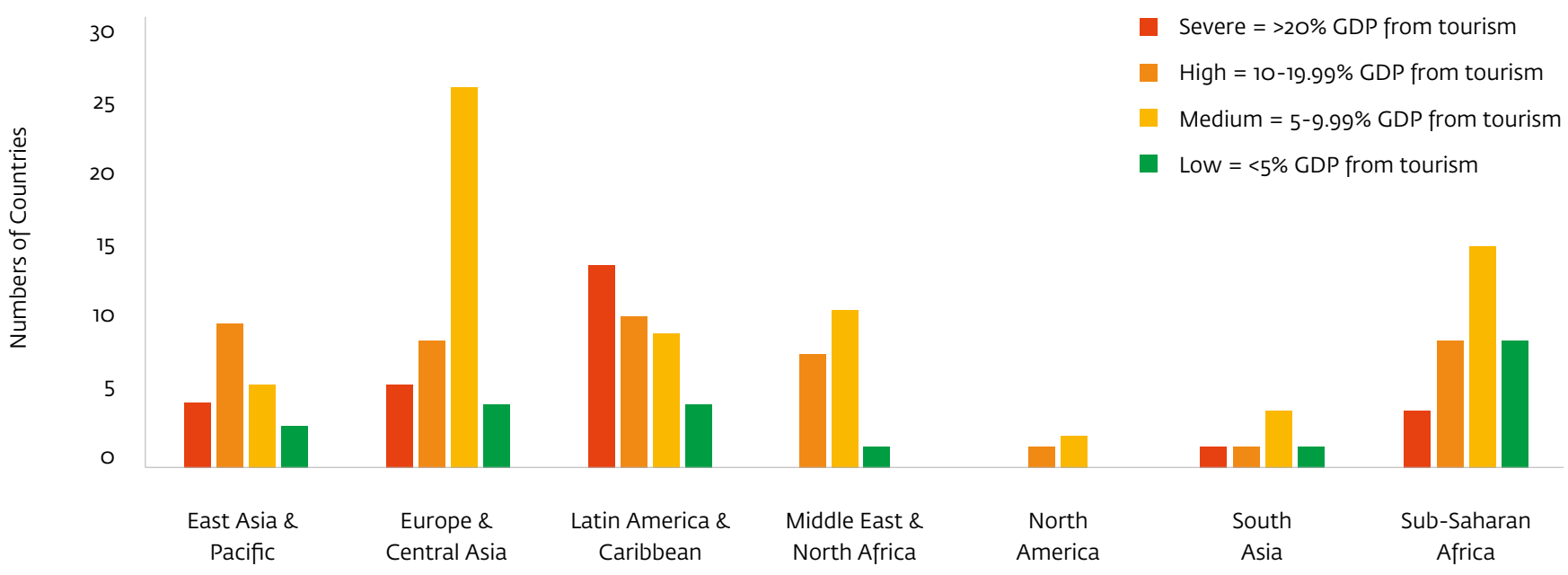

Figure 18. Total Contribution of Travel and Tourism to GDP, by Country with Severe, High, Medium or Low Dependency (WTTC, 2019)

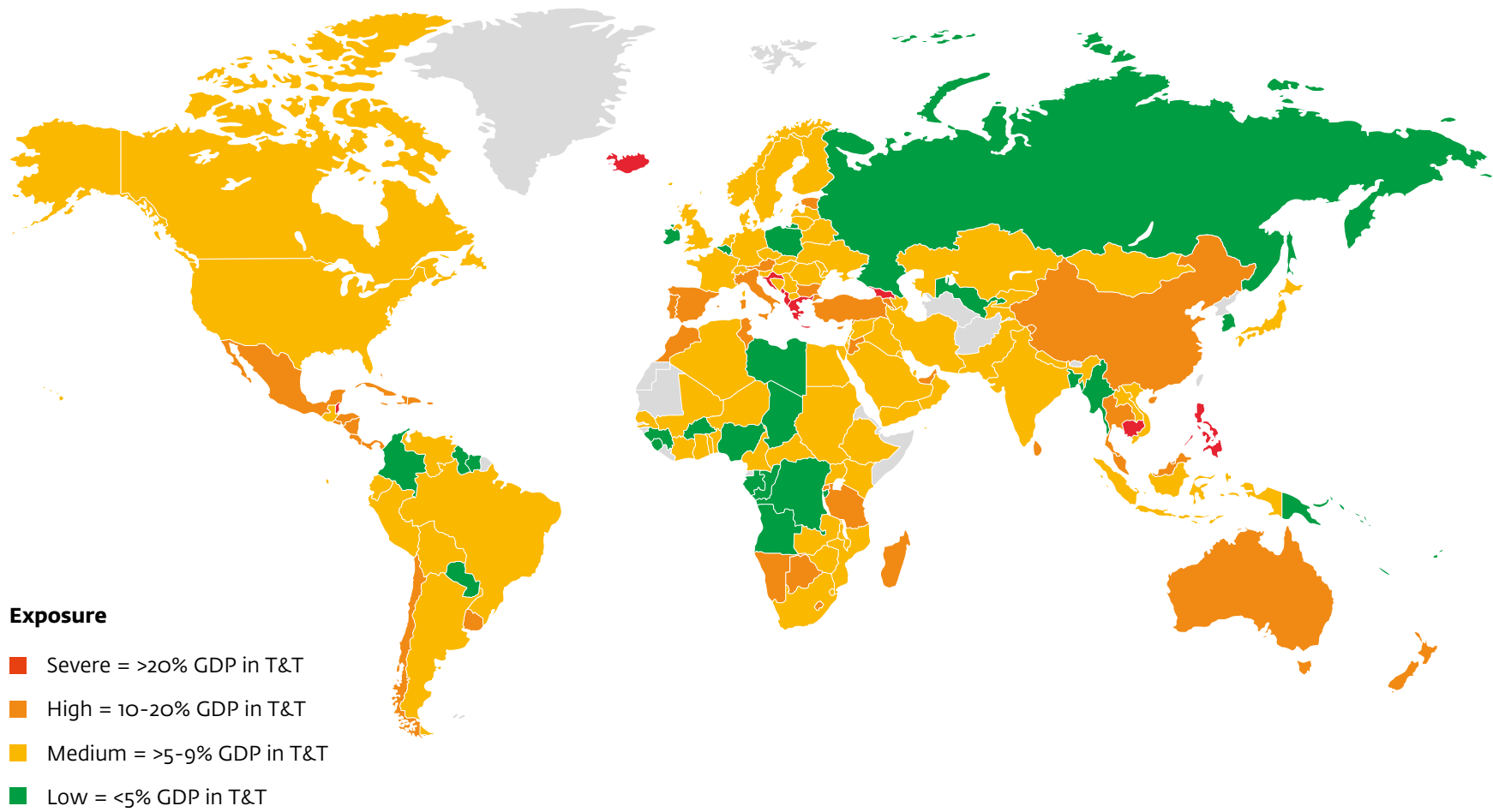




\title{
Appendix 3: Menu of Response Options
}

\author{
Table 3. Response Options by Tourism Subsector
}

\begin{tabular}{|c|c|c|}
\hline Sub-sector & Phase 1: Containment and immediate post-crisis response & Phase 2: Recovery/medium-term \\
\hline $\begin{array}{l}\text { Accommodation } \\
\text { and lodging }\end{array}$ & 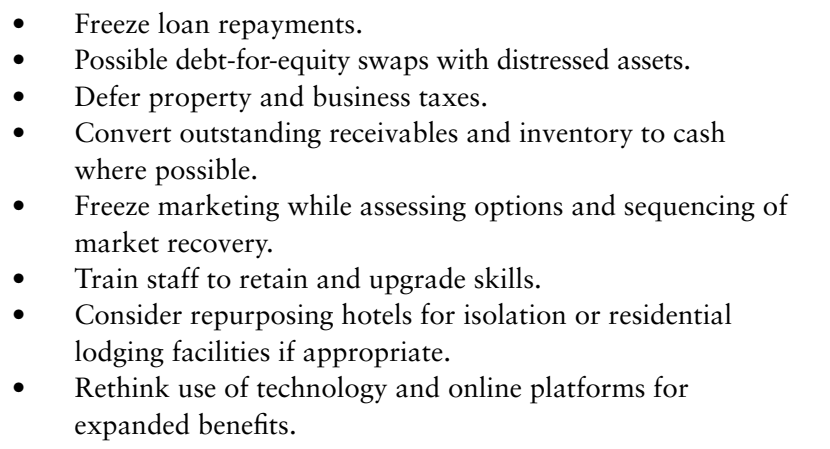 & $\begin{array}{l}\text { - } \quad \text { Restructure balance sheets when cash } \\
\text { is available. } \\
\text { - } \quad \text { Exit equity once upturn stabilizes. } \\
\text { Mobilize capital for acquisition of distressed } \\
\text { sales so that available operating stock can } \\
\text { bounce back quickly. } \\
\text { - Support destination management } \\
\text { organizations and associations in destination } \\
\text { renewal and repositioning efforts. } \\
\text { Continue training initiatives to enable } \\
\text { certification and career paths. }\end{array}$ \\
\hline Airlines & $\begin{array}{l}\text { - } \quad \text { Government/airport owners/operators to waive all airport- } \\
\text { - } \quad \text { Underwrite select carriers to keep operations open. } \\
\text { - } \quad \text { Freeze asset purchases. } \\
\text { - } \quad \text { Maintain cargo operations to keep goods moving. } \\
\text { - } \quad \text { Offer staff (paid) training schemes. } \\
\text { - Utilize seat subsidies selectively. }\end{array}$ & $\begin{array}{l}\text { - Reassess priority routes including } \\
\text { identification of new, high potential routes. } \\
\text { Selective ticket promotions for building of } \\
\text { off-season or shoulder period activity. }\end{array}$ \\
\hline Tour operators & $\begin{array}{l}\text { - } \\
\text { - } \quad \text { Expand and systematically conduct staff training for } \\
\text { additional skills and to enhance quality. } \\
\text { - } \quad \text { Freeze loan repayments. } \\
\text { Maintain supplier linkages. }\end{array}$ & $\begin{array}{l}\text { - } \quad \text { Assistance in rebuilding supplier networks. } \\
\text { enpport programs that foster } \\
\text { entrepreneurship especially in the } \\
\text { development of new tourism products and } \\
\text { innovative offerings to attract new markets. } \\
\text { Expand supplier linkages. }\end{array}$ \\
\hline Cruise & $\begin{array}{l}\text { - } \quad \text { Government/port owners/operators to waive port-related fees. } \\
\text { provider repurposing vessels to support health efforts and to } \\
\text { Assess impacts on ports that are primarily ports of call for } \\
\text { day visitors versus those which are refueling and restocking } \\
\text { ports or home ports. } \\
\text { Plan for shifting local supply activities and amenities to } \\
\text { focus on overnight visitors that fly in and out of destinations } \\
\text { through demand analysis and support the development } \\
\text { of new tourism product (for example, SMEs for tourism } \\
\text { amenities, tours, experiences). }\end{array}$ & $\begin{array}{l}\text { Rebuild confidence of consumers and } \\
\text { receiving ports through specific marketing } \\
\text { campaigns to overcome negative image of the } \\
\text { industry as part of the cause of the problem, } \\
\text { i.e., Princess cruise ship saga in Japan. } \\
\text { Leverage extensive experience of cruise } \\
\text { subsector in recovering from health crises. }\end{array}$ \\
\hline $\begin{array}{l}\text { Other linked } \\
\text { sectors and } \\
\text { related GVCs }\end{array}$ & $\begin{array}{l}\text { - } \quad \text { MSME needs assessment and credit facilities through local } \\
\text { commercial banks. } \\
\text { - } \quad \text { Cash payments to retain staff. } \\
\text { Training to improve health and hygiene levels for recovery. }\end{array}$ & $\begin{array}{l}\text { - Formalize capacity to foster cross-sector } \\
\text { collaboration and PPD. } \\
\text { Market reengagement as part of national } \\
\text { relaunch program. } \\
\text { Ongoing skills and quality training; } \\
\text { certification programs that improve standards. }\end{array}$ \\
\hline
\end{tabular}




\begin{tabular}{|c|c|c|c|}
\hline Tourism & $\begin{array}{l}\text { Phase 1: Containment/ } \\
\text { short-term }\end{array}$ & $\begin{array}{l}\text { Phase 2: Recovery/ } \\
\text { medium-term }\end{array}$ & $\begin{array}{l}\text { Comments and country } \\
\text { examples }\end{array}$ \\
\hline $\begin{array}{l}\text { Government } \\
\text { coordination } \\
\text { and sector-based } \\
\text { health responses }\end{array}$ & $\begin{array}{l}\text { Work with government and private } \\
\text { sector to establish and support a Crisis } \\
\text { Response and Recovery Task Force. } \\
\text { Use this platform to: } \\
\text { - } \quad \text { Collect and analyze firm level } \\
\text { data regarding revenue losses, job } \\
\text { losses, and fiscal impacts. } \\
\text { - Collate and share international } \\
\text { best practices. } \\
\text { - Coordinate development/donor } \\
\text { partners around specific short- } \\
\text { term crisis response; develop } \\
\text { analysis of regulatory and } \\
\text { taxation for streamlining that can } \\
\text { contribute to recovery. } \\
\text { Communicate common messaging } \\
\text { to and with source markets and } \\
\text { source market suppliers. } \\
\text { Facilitate health responses to } \\
\text { adapt and restructure sector and } \\
\text { businesses. }\end{array}$ & $\begin{array}{l}\begin{array}{l}\text { Lead planning and implementation of } \\
\text { 'build-back-better' initiatives. }\end{array} \\
\text { - } \quad \text { Use information collected in the } \\
\text { first 6-12 months to develop a } \\
\text { recovery strategy focused on } \\
\text { building back a more resilient } \\
\text { and sustainable industry. } \\
\text { Improve tourism information } \\
\text { and data management systems. } \\
\text { Implement recovery planning to } \\
\text { build resilience and sustainability. }\end{array}$ & $\begin{array}{l}\text { Crises cut across government agencies } \\
\text { and activities - just as tourism does. } \\
\text { Therefore, encouraging and enabling } \\
\text { governments to coordinate more } \\
\text { (and in ways that are not 'normal' } \\
\text { for them) is an important first step. } \\
\text { It communicates to the private sector } \\
\text { and communities that this is not } \\
\text { 'business as usual' for the government } \\
\text { or the private sector. Phase } 1 \text { and } 2 \text { are } \\
\text { an unusual situation that empowers } \\
\text { government to do different and better } \\
\text { than usual. }\end{array}$ \\
\hline Commu & $\begin{array}{l}\text { Accept and embrace travel bans. } \\
\text { - } \quad \text { Adopt tourism policy that } \\
\text { embraces public health directives. } \\
\text { Cease marketing of any kind, } \\
\text { urging everyone to stay at home. } \\
\text { Expand timely and honest } \\
\text { communication. } \\
\text { - Tourism boards and destination } \\
\text { management organizations } \\
\text { should adopt a proactive role } \\
\text { to communicate and inform } \\
\text { the industry and public about } \\
\text { latest developments affecting the } \\
\text { destination. } \\
\text { Work to position the destination } \\
\text { as responsible and build trust } \\
\text { through providing cogent } \\
\text { information to all stakeholders. }\end{array}$ & 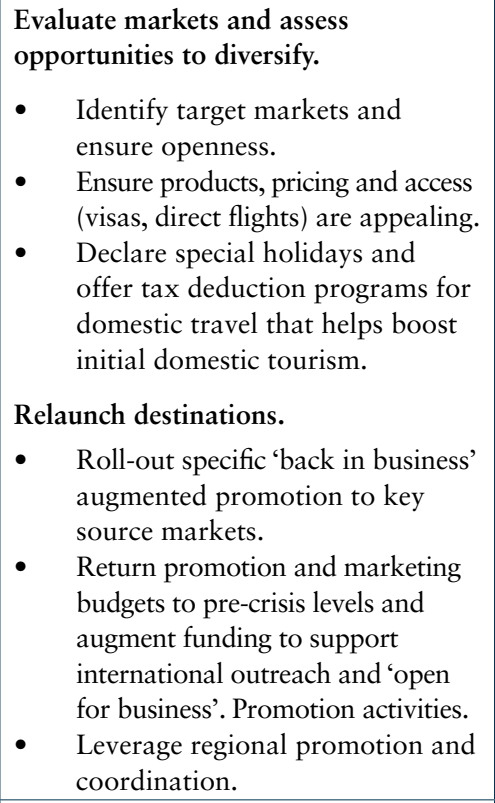 & $\begin{array}{l}\text { Past experiences of a wide range of } \\
\text { crises that have impacted tourism } \\
\text { show that consistent and clear } \\
\text { communication throughout is integral } \\
\text { to i) engaging stakeholders through } \\
\text { the most challenging times and during } \\
\text { recovery; and ii) consistent, clear } \\
\text { communication (of good news and } \\
\text { not so good news) builds consumer } \\
\text { engagement later. }\end{array}$ \\
\hline $\begin{array}{l}\text { Financial and } \\
\text { job-saving } \\
\text { responses }\end{array}$ & $\begin{array}{l}\text { Property tax rebates or payment deferrals } \\
\text { for hotels and other tourism businesses, } \\
\text { including for tenants in government } \\
\text { properties, parks or facilities. } \\
\text { Fee waivers by national carriers and } \\
\text { other commercial airlines. } \\
\text { - Subsectors - especially air transport } \\
\text { and cruise lines to take measures } \\
\text { to inspire confidence in booking } \\
\text { flights by waiving change and/or } \\
\text { cancellation fees for future bookings. }\end{array}$ & $\begin{array}{l}\text { Lower or eliminate arrival fees and } \\
\text { related taxes for key flights from } \\
\text { traditional and new key source } \\
\text { markets. } \\
\text { - } \quad \text { Consider subsidizing air transport } \\
\text { tickets (small fee paid by } \\
\text { government, motivating agents to } \\
\text { sell tickets at a perceived lower cost) } \\
\text { utilized carefully and selectively for } \\
\text { limited time periods to kick-start a } \\
\text { low or usually high season. }\end{array}$ & $\begin{array}{l}\text { - The United Kingdom government } \\
\text { has announced a } 100 \text { percent } \\
\text { business rates holiday for the } \\
\text { next } 12 \text { months to cover all } \\
\text { retail, hospitality, and leisure } \\
\text { businesses. }\end{array}$ \\
\hline
\end{tabular}




\begin{tabular}{|c|c|c|c|}
\hline Tourism & $\begin{array}{l}\text { Phase 1: Containment/ } \\
\text { short-term }\end{array}$ & $\begin{array}{l}\text { Phase 2: Recovery/ } \\
\text { medium-term }\end{array}$ & $\begin{array}{l}\text { Comments and country } \\
\text { examples }\end{array}$ \\
\hline Liquidity/grants & $\begin{array}{l}\text { Government grants or subsidies to } \\
\text { businesses specifically to help contain } \\
\text { the spread of the virus. } \\
\text { Wage subsidies to keep paying staff. } \\
\text { Support small grants for vulnerable } \\
\text { businesses deployed to support } \\
\text { enterprises with liquidity concerns. }\end{array}$ & $\begin{array}{l}\text { Improve access to finance for } \\
\text { registered tourism businesses. } \\
\text { - } \quad \text { Assess, prioritize, and facilitate } \\
\text { access to finance on favorable } \\
\text { terms for key tourism SMEs } \\
\text { by creating a guarantee facility } \\
\text { managed through government } \\
\text { and private sector associations. } \\
\text { - Digitize licensing, registration } \\
\text { and government to business } \\
\text { interactions and payments. } \\
\text { Support recovery through } \\
\text { integrated WBG instruments } \\
\text { leveraging grant financing and } \\
\text { COVID-19 emergency funds. }\end{array}$ & $\begin{array}{l}\text { - In Jamaica, for example, the } \\
\text { government launched a Business } \\
\text { Employee Support and Transfer } \\
\text { (BEST), which will provide } \\
\text { temporary cash transfers to } \\
\text { businesses operating in the } \\
\text { hotels, tours, and attractions of } \\
\text { the tourism sector. Kenya and } \\
\text { Morocco are working on similar } \\
\text { packages. } \\
\text { In New Zealand, businesses hard- } \\
\text { hit by the virus (experiencing } \\
\text { more than a } 30 \text { percent decline in } \\
\text { revenue compared with last year) } \\
\text { will be eligible to receive wage } \\
\text { subsidies. } \\
\text { The United Kingdom is offering } \\
\text { further support of up to } £ 25,000 \\
\text { for businesses in hospitality, } \\
\text { leisure, and retail. } \\
\text { Singapore is supporting third- } \\
\text { party cost of professional } \\
\text { cleaning services incurred by } \\
\text { Singapore-licensed hotels that } \\
\text { have provided accommodation } \\
\text { to suspected and confirmed } \\
\text { COVID-19 case(s). }\end{array}$ \\
\hline $\begin{array}{l}\text { Training/ } \\
\text { upskilling } \\
\text { to keep jobs } \\
\text { and improve } \\
\text { competitiveness }\end{array}$ & $\begin{array}{l}\text { Subsidized training for tourism } \\
\text { industry workers to forestall layoffs. } \\
\text { - } \quad \text { Enable a subsidy for employers } \\
\text { to keep workers on their payrolls } \\
\text { instead of laying them off, with } \\
\text { the added incentive of upskilling } \\
\text { workers and boosting their } \\
\text { productivity. when their services } \\
\text { are again needed in the post-crisis } \\
\text { period. } \\
\text { Support that enables an increase } \\
\text { in standards and delivery of } \\
\text { services. }\end{array}$ & $\begin{array}{l}\text { Reassure and retain staff at all levels } \\
\text { for the long-term. } \\
\text { Overcome reputation of the } \\
\text { sector for instability and sudden } \\
\text { job loss with an active focus on } \\
\text { the longevity and longer-term } \\
\text { opportunities in the tourism } \\
\text { sector for employment. } \\
\text { Enhance health, hygiene, and } \\
\text { emergency response training for } \\
\text { all staff. }\end{array}$ & $\begin{array}{l}\text { In response to various crises, } \\
\text { workers in Singapore have } \\
\text { enrolled in government-funded } \\
\text { training programs and are being } \\
\text { paid a portion of their salary } \\
\text { (90 percent of wages for hourly } \\
\text { workers). } \\
\text { In Samoa, when several large } \\
\text { hotels were suddenly inoperable } \\
\text { due to a hurricane, staff from } \\
\text { those hotels were temporarily } \\
\text { absorbed for 'training' in the } \\
\text { remaining hotels with their } \\
\text { 'wages' funded through donor } \\
\text { support. } \\
\text { In St. Maarten, following Hurricane } \\
\text { Irma, employees from highly } \\
\text { damaged hotels were channeled } \\
\text { into government sponsored training } \\
\text { programs while hotels were rebuilt. } \\
\text { Time in training was paid for in the } \\
\text { form of wages. }\end{array}$ \\
\hline
\end{tabular}




\begin{tabular}{|c|c|c|c|}
\hline Tourism & $\begin{array}{l}\text { Phase 1: Containment/ } \\
\text { short-term }\end{array}$ & $\begin{array}{l}\text { Phase 2: Recovery/ } \\
\text { medium-term }\end{array}$ & $\begin{array}{l}\text { Comments and country } \\
\text { examples }\end{array}$ \\
\hline $\begin{array}{l}\text { Plan and invest } \\
\text { in recovery }\end{array}$ & $\begin{array}{l}\text { Promote planning for post-crisis } \\
\text { itineraries and booking of travel and } \\
\text { accommodation. } \\
\text { - } \quad \text { Provide forward credits (rather } \\
\text { than refunds where appropriate). } \\
\text { Engage online services in travel } \\
\text { and tourism for maximum } \\
\text { utilization of digital platforms } \\
\text { and technology. }\end{array}$ & $\begin{array}{l}\text { Foster and support entrepreneurship. } \\
\text { - } \quad \text { Emphasize creation of new and } \\
\text { innovative products that can } \\
\text { help build visitor volume and } \\
\text { encourage previous visitors to } \\
\text { return for 'something familiar' } \\
\text { and 'something new'. } \\
\text { Incentivize business expansion } \\
\text { and entrepreneurship through } \\
\text { waivers for permit/license fees } \\
\text { (both new issuance and renewals) } \\
\text { for hotels, travel agents, and } \\
\text { tour guides, and transportation } \\
\text { services such as taxis. } \\
\text { Enhance access and establish } \\
\text { additional global gateways } \\
\text { by reducing landing fees and } \\
\text { passenger airport taxes and } \\
\text { expanding access to and from } \\
\text { individual countries with } \\
\text { increased flights as operational } \\
\text { supply reopens. }\end{array}$ & \\
\hline $\begin{array}{l}\text { Support sector } \\
\text { sustainability }\end{array}$ & $\begin{array}{l}\text { Build caring profile of the sector. } \\
\text { - Consistent communication that } \\
\text { tourism is a resilient industry and } \\
\text { that it will support communities } \\
\text { throughout the crisis and } \\
\text { afterwards during recovery. } \\
\text { Strengthen sector cohesiveness } \\
\text { and longevity through genuine } \\
\text { support for employees, businesses, } \\
\text { communities, and others, in crisis } \\
\text { period. }\end{array}$ & $\begin{array}{l}\text { Enhance specific regulations enabling } \\
\text { sustainability and competitiveness. } \\
\text { - } \quad \text { Define zoning policies to } \\
\text { assure sustainable development } \\
\text { particularly in areas of cultural } \\
\text { heritages sites. } \\
\text { Develop and enforce zoning } \\
\text { guidelines in urban and rural } \\
\text { areas to protect green areas, } \\
\text { protect cultural heritage, and } \\
\text { assure sustainable development } \\
\text { going forward. } \\
\text { Expand current programs and } \\
\text { incentives for greening of the } \\
\text { tourism sector and increase } \\
\text { awareness of sustainable } \\
\text { development such as incentivizing } \\
\text { use of renewable energy sources } \\
\text { and green technologies. }\end{array}$ & $\begin{array}{l}\text { In previous crises, hotels have provided } \\
\text { emergency lodging and shelter for } \\
\text { victims. This has built enormous } \\
\text { goodwill that carries through recovery } \\
\text { and the next crisis. The tourism sector } \\
\text { - with its fundamental elements of } \\
\text { transportation, lodging, and services } \\
\text { - is uniquely positioned to 'host' } \\
\text { these acts, which are remembered } \\
\text { long after the specific crisis. During } \\
\text { 9/11, hotels in Ground Zero provided } \\
\text { emergency meals and support to } \\
\text { communities in the immediate vicinity } \\
\text { that built commitment to the sector } \\
\text { for years to come (and even now as } \\
\text { they face COVID-19). }\end{array}$ \\
\hline
\end{tabular}


Figure 19. International Examples of Specific Measures to Support the Tourism Sector

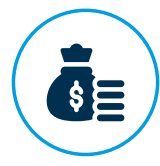

Liquidity injection cost reduction

Armenia: Cash transfer to support workers and entrepreneurs in the tourism sector and retail (US\$137-274).

Italy: $€ 600$ one-time payment for self-employed and professionals in the agricultural, tourism and cultural sectors.

Malaysia: (a) double deduction in expenditures used to provide training in tourism and related sectors (b) provide RM50 million to finance short courses in digital and high level skills (100,000 beneficiaries).

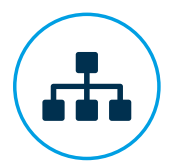

Adaptation and sector restructuring (health and safety standards, protocols)

Chile: Toolkit to reactivate the sector, designed with input by key stakeholders and institutions.

Singapore: 7 points

standard hygiene program

for hotels and other

services, campaign 'SG

Clean'.

Portugal: Health and hygiene standards ('Clean and Safe').

New Zealand/Australia:

'Bubble' to allow travel

between the two

destinations.

Albania: Protocol of 7 rules to re-opening the beaches.

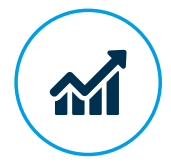

Improvement to the tourism offering (services, infrastructure, locations, experience)

Argentina: US\$10omillion for public works in tourism, house renovation, schools and kindergarten.

China: 346 construction projects identified to be financed by the central government.

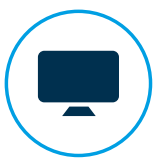

Use of digital tools and platforms

Chile:

- $\quad$ Free online webinars and talks on tourismrelated issues.

- Technical assistance to improve business management processes and digital skills for tourism entrepreneurs.

Egypt/lsrael/Greece: Online tours of cities and attractions.

New Zealand/Australia: Delivery services for restaurants and other businesses using digital platforms.

Singapore: Application and promotion of digital payment tools, such as mobile wallets and others, to avoid contact. 


\section{Endnotes}

https://www.unwto.org/news/covid-19-world-tourism-remains-at-a-standstill-as-100-of-countries-impose-restrictions-on-travel https://www.wttc.org/about/media-centre/press-releases/press-releases/2020/latest-research-from-wttc-shows-an-increase-injobs-at-risk-in-travel-and-tourism/

3 http://www.oecd.org/cfe/COVID-19-SME-Policy-Responses.pdf

4 https://cdn.centreforaviation.com/analysis/reports/covid-19-by-the-end-of-may-most-world-airlines-will-be-bankrupt-517512 https://www.ahla.com/covid-19s-impact-hotel-industry

https://www.cdc.gov/media/releases/2020/s0409-modifications-extension-no-sail-ships.html

https://www.forbes.com/sites/greatspeculations/2020/04/06/norwegian--royal-caribbean-down-80-is-either-now-a-goodvalue/\#5c078536529d

https://www.fool.com/investing/2020/04/11/why-royal-caribbean-carnival-and-norwegian-cruise.aspx Depoux, A., Martin, S., Karafillakis, E., Preet, R., Wilder-Smith, A., and Larson, H. "The pandemic of social media panic travels faster than the COVID-19 outbreak”. Centre Virchow-Villerme, Paris, France London School of Hygiene and Tropical Medicine, London, U.K. Department of Epidemiology and Global Health, Umeå University, Umeå, Sweden. (American Airlines in 2010; U.S. Airways in 2002 and 2004; Delta and Northwest in 2007 and United in 2002). As of 2013, the nine major airlines had consolidated through mergers and acquisitions into just four airlines (American Airlines [which acquired America West, which had previously acquired U.S. Airways]; Delta [which acquired Northwest]; United [which merged with Continental]; and Southwest [which acquired AirTran]). (https://money.cnn.com/infographic/news/companies/ airline-merger/).

https://str.com/press-release/str-us-hotel-results-week-ending-11-april

COVID-19 - a global insight on travel and tourism impacts UNWTO \& Data Partners 21 April 2020.

https://www.hospitalitynet.org/opinion/4097673.html

https://str.com/data-insights-blog/covid-19-webinar-summary-5-key-points-latin-america-hotel-performance-24-march https://www.wttc.org/members-hub/

The World Bank (2018) Tourism and the Sharing Economy: Policy and Potential of Peer-to-Peer Accommodation.

22 tour operators contacted across Tanzanian and Ugandan markets confirmed similar trends.

https://cruising.org/-/media/research-updates/research/state-of-the-cruise-industry.pdf

IFC, Assessment of the Economic Impact of Cruise Ships to Vanuatu, 2014.

https://www.cdc.gov/mmwr/volumes/69/wr/mm6912e3.htm?s_cid=mm6912e3_e

https://www.cdc.gov/media/releases/2020/s0409-modifications-extension-no-sail-ships.html

https://time.com/5802661/coronavirus-cancellations-workers/

https://story.californiasunday.com/below-deck

https://edition.cnn.com/2020/04/01/business/carnival-cruise-debt-coronavirus/index.html

World Bank (2018) The Voice of Travelers: Managing User-Generated Content for Sustainable Tourism Development. https://www.phocuswire.com/expedia-layoffs-streamlines-operations

https://ir.expediagroup.com/news-releases/news-release-details/expedia-group-withdraws-2020-guidance-due-covid-19-impact https://www.webintravel.com/sabre-makes-over-us200-million-in-cuts-in-response-to-covid-19/

https://www.businessinsider.es/impacto-economico-mobile-world-congress-barcelona-377975

https://www.bloomberg.com/news/articles/2020-03-11/clipped-wings-virus-kills-a-16-year-boom-for-boeing-and-airbus 
https:/umassociation.wpengine.com/wp-content/uploads/sites/4/2020/03/Dunham-Econ-Impact-031620.pdf

WTTC (2019) Economic Impact Country Analysis. https://www.wttc.org/economic-impact/

WEF (2019) The Travel \& Tourism Competitiveness Report 2019 Travel and Tourism at a Tipping Point.

https://www3.weforum.org/docs/WEF_TTCR_2019.pdf

39 Categorized as a small island developing state by UNSIDS.

40 As noted in WEF 2019 p. 86, TTCI is calculated as an average (arithmetic mean) of the four component sub-indices (sum of all observations over count of observations), which are themselves calculated as averages (arithmetic means) of their pillars. Each of the pillars is calculated as an un-weighted average of the individual component variables.

41 A sensitivity analysis was conducted and verified that the pillars are closely correlated, so no weighting was applied (correlation coefficient of 0.96 for both income categories - Spearman Rank Order correlation, statistically significant at the 99 percent confidence interval).

42 World Bank Group. "Support to Systematically Large Firms in Hard-Hit Sectors: The Case of Airlines Stat-Support Programs amid COVID-19”. FCI Global Markets \& Technology Unit. June 29, 2020.

43 Live updates at: http://wbgmssqlefip001.worldbank.org/Analytics/powerbi/Topic/MAT/IND-COVID19

442008 IEG Report "Lessons from World Bank Group Support to Previous Financial Crises".

45 https://www.mckinsey.com/business-functions/risk/our-insights/covid-19-implications-for-business

46 https://www.mckinsey.com/business-functions/risk/our-insights/covid-19-implications-for-business

$47 \mathrm{http}: / /$ documents.worldbank.org/curated/en/478761584725100731/pdf/WBG-Support-for-Tourism-Clients-andDestinations-During-the-COVID-19-Crisis.pdf?deliveryName=DM57356

https://blogs.worldbank.org/voices/we-cant-travel-we-can-take-measures-preserve-jobs-tourism-industry

$48 \mathrm{https}: / /$ twitter.com/visitestonia/status/1238885142237773838

49 https://www.straitstimes.com/asia/east-asia/hong-kong-to-quarantine-all-people-entering-the-city-from-thursday

so https://www.fsb.org.uk/campaign/covid19.html

${ }^{51}$ https://www.fsb.org.uk/campaign/covid19.html

52 https://mof.gov.jm/mof-media/media-centre/press/2633-fiscal-stimulus-response-to-the-covid-19.html

53 https://www.newshub.co.nz/home/politics/2020/03/covid-19-12-billion-package-includes-wage-subsidies-tax-relief-andsick-leave-support-amid-coronavirus-pandemic.html

${ }_{54}$ https://www.irrawaddy.com/news/burma/myanmar-govt-suspends-advance-tax-exports-aid-virus-hit-businesses.html

55 https://www.theguardian.com/world/2020/mar/17/new-zealand-launches-massive-spending-package-to-combat-covid-19

56 https://www.stb.gov.sg/content/stb/en/assistance-and-licensing/Support-for-Cleaning-Disinfection-Costs.html

57 https://www.wsj.com/articles/new-york-city-weighs-turning-hotels-into-hospitals-11584556841

58 https://www.travelmole.com/news_feature.php?c=setreg\&region=3\&m_id=s $\sim$ bmmbs $\sim$ \&w_id=37375\&news_id=2042120

59 https://www.smithsonianmag.com/smart-news/you-can-thank-these-depression-era-workers-your-national-parks-180960284/

60 https://www.unwto.org/covid-19-oneplanet-responsible-recovery; Ioannides, Dimitri \& Gyimóthy, Szilvia. (2020). The COVID-19 crisis as an opportunity for escaping the unsustainable global tourism path. Tourism Geographies. 1-9. 10.1080/14616688.2020.1763445. 


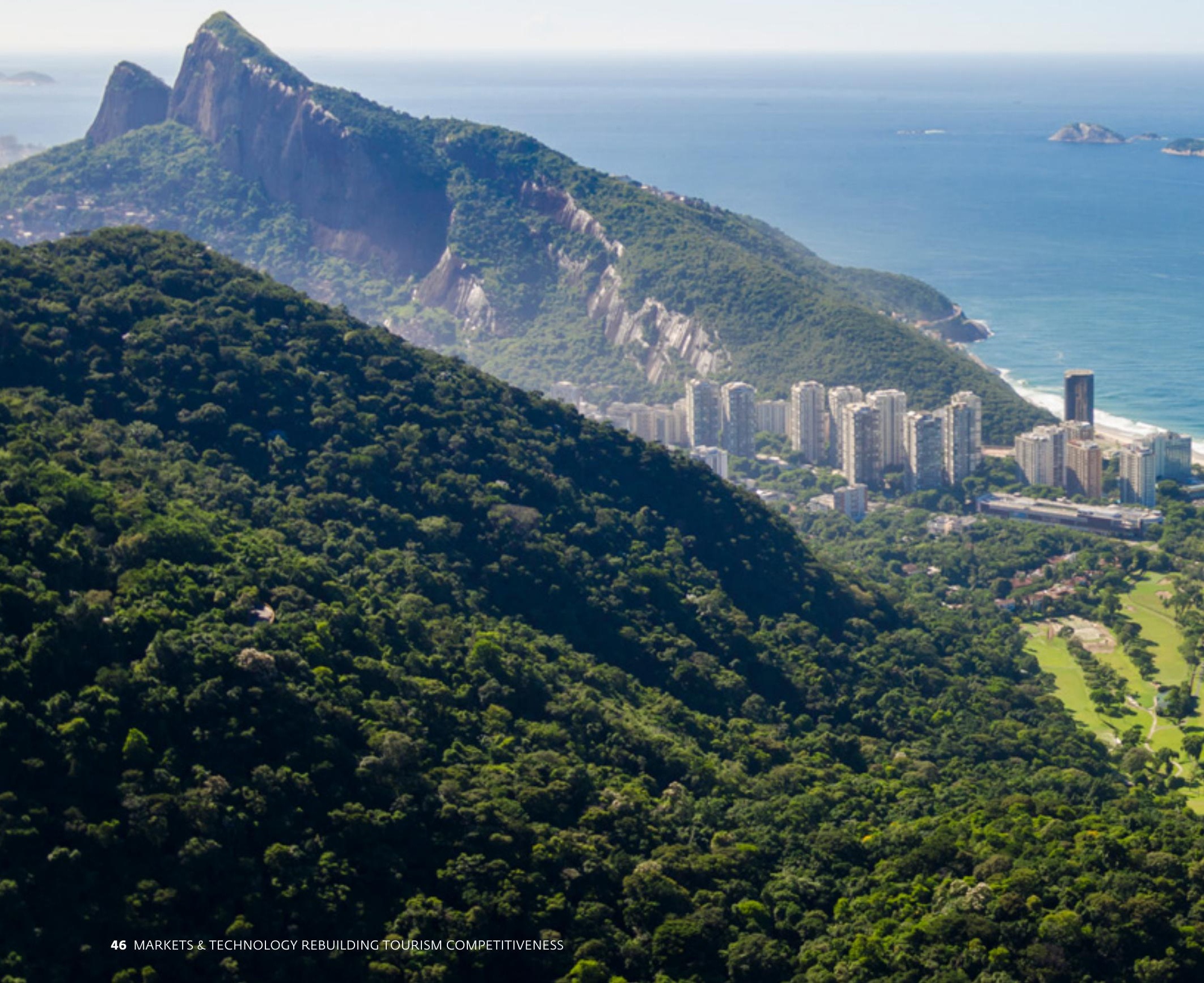




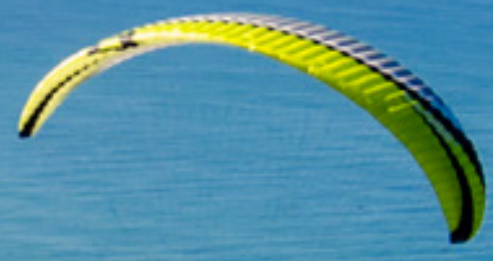

\section{$*$}

$x+\frac{1}{3}$

Litis

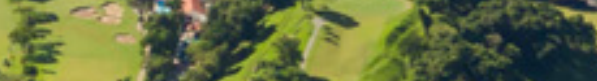

s.

20

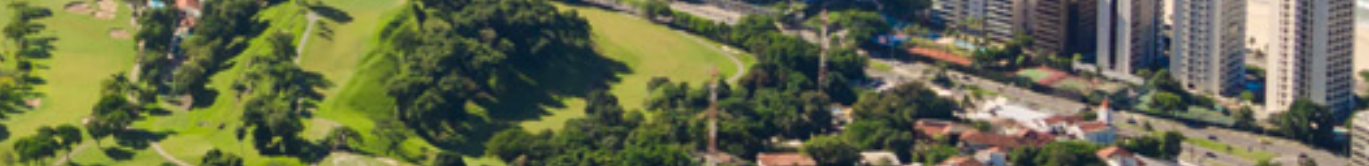

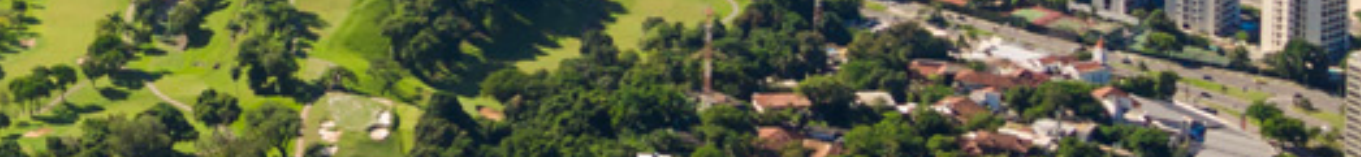

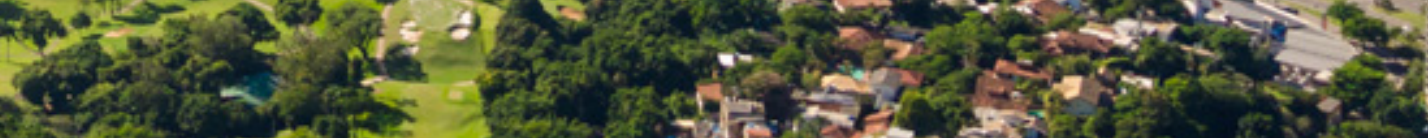

(1)

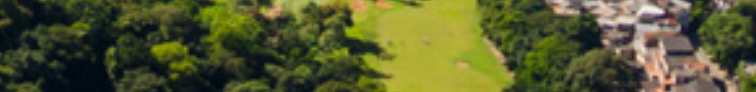


Email us at tourism@worldbankgroup.org

Engage with us on social media at \#tourism4dev

(c) 2020 The World Bank Group 